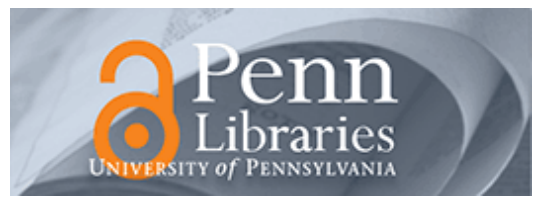

University of Pennsylvania

ScholarlyCommons

Accounting Papers

Wharton Faculty Research

$3-2012$

\title{
Frictions in the CEO Labor Market: The Role of Talent Agents in CEO Compensation
}

Shivaram Rajgopal

Daniel J. Taylor

University of Pennsylvania

Mohan Venkatachalam

Follow this and additional works at: https://repository.upenn.edu/accounting_papers

Part of the Accounting Commons

\section{Recommended Citation}

Rajgopal, S., Taylor, D. J., \& Venkatachalam, M. (2012). Frictions in the CEO Labor Market: The Role of Talent Agents in CEO Compensation. Contemporary Accounting Research, 29 (1), 119-151.

http://dx.doi.org/10.1111/j.1911-3846.2011.01082.x

This paper is posted at ScholarlyCommons. https://repository.upenn.edu/accounting_papers/5

For more information, please contact repository@pobox.upenn.edu. 
Frictions in the CEO Labor Market: The Role of Talent Agents in CEO Compensation

\section{Disciplines}

Accounting 


\title{
Frictions in the CEO Labor Market: The Role of Talent Agents in CEO Compensation
}

\author{
Shiva Rajgopal* \\ University of Washington Business School \\ Daniel Taylor \\ Graduate School of Business, Stanford University \\ Mohan Venkatachalam \\ Fuqua School of Business, Duke University
}

April 2010

\begin{abstract}
:
Standard principal-agent models commonly invoked to explain executive pay practices do not account for the involvement of third-party intermediaries in the CEO labor market. This paper investigates the influence of one such intermediary - talent agents who seek out prospective employers and negotiate pay packages on behalf of CEOs. Jensen, Murphy and Wruck (2004) characterize the hiring of such agents as an obvious example of rent extraction by incoming CEOs. After controlling for economic factors, proxies for governance quality, and determinants of the CEO's reservation wage, the first year compensation of CEOs who use these agents is significantly higher by about $\$ 10$ million relative to the pay of CEOs who do not use such agents. Further analysis suggests that firms run by CEOs who use talent agents report superior future operating and stock performance, suggesting that these CEOs are not extracting rents at the expense of shareholders.
\end{abstract}

*Corresponding author: Box 353200, Seattle, WA 98195, Tel. 206543 7913; Fax 2066859392

Email: rajgopal@u.washington.edu. We thank Brian Gaither for excellent RA support, and John Core, Stuart Gillian, Wayne Guay, Rick Lambert, Katherine Schipper, Cathy Schrand, Suraj Srinivasan, Randall Thomas, David Yermack, and workshop participants at the 2006 AAA conference, 2006 FEA conference, University of Pennsylvania, University of Washington and Washington University - St. Louis for comments. We thank our respective schools for financial support, and Daniel Taylor gratefully acknowledges funding from the Deloitte Foundation. 


\section{The Role of Talent Agents in CEO Compensation}

\subsection{Introduction}

The standard principal-agent paradigm is often invoked in finance and accounting research to understand the CEO labor market. In this paradigm, the board of directors is assumed to negotiate at arms length with the CEO, and the optimal contract ties CEO compensation to shareholder wealth. However, the presence of third-party intermediaries such as executive search firms, compensation consultants, and talent agents who represent CEOs suggests the existence of significant labor market frictions that do not appear in standard principal-agent models. ${ }^{1}$

While much of the managerial accounting literature explores the relation between pay and performance (e.g., Lambert and Larker, 1987) only recently has the literature begun to explore the role of individual actors and intermediaries in the CEO selection and pay setting process. In a field study, Khurana (2002) investigates the role of executive search firms in hiring CEOs. Kaplan, Klebanov and Sorenson (2008) document the important characteristics and abilities of candidate CEOs based on detailed assessments by private equity investors. An emerging stream of literature exploits proxy disclosures for years 2007 and beyond to examine whether the use of compensation consultants is associated with higher CEO pay (e.g., Murphy and Sandino 2008; Armstrong et al. 2009a; Cadman et al. 2009). While considerable research has examined how executive talent manifests itself in earnings quality (e.g., Francis et al., 2008), managers' earnings forecasts (e.g., Bamber et al., 2008), and earnings management (e.g., Ge et al. 2009; Hanlon et al. 2009), the literature has paid limited attention to how talented executives are recruited and hired. We attempt to fill this void in the literature by focusing on the role of talent agents in the pay setting process.

\footnotetext{
${ }^{1}$ Note that in the "plain vanilla" principal-agent model, the bargaining power is with the principal who makes a take-it-or-leave-it offer to the candidate CEO. In this setting multiple firms are not competing over the candidate's skills and his opportunity cost is exogenously specified. One alternative characterization of the CEO labor market is an auction-like setting where firms bid over scarce CEO talent. In this setting the equilibrium strategy for firm $i$ is the 'best response' to firm $j$ 's best response,' effectively endogenizing the CEO's opportunity cost (i.e., the next highest bid).
} 
Talent agents typically negotiate pay packages on behalf of incoming CEOs and try to secure alternative job opportunities for their client CEOs. Anecdotal and empirical evidence indicates that the importance of such agents has risen sharply in recent years, as CEO turnover has accelerated in the last decade and major corporations increasingly look to hire CEOs from outside the firm (Schellhardt 1998; Hermalin 2005; and Murphy and Zabojnik 2004). The financial press and academic case studies are replete with stories about lavish pay packages, perquisites and other contracting arrangements that talent agents are able to extract from the firm on behalf of the CEO (Fredman 2001; Sachdev 2003; Barro, Hall and Zimmerman 2004; Jensen, Murphy and Wruck 2004). Jensen et al. (2004) characterize the use of such agents as one obvious example of how CEOs skim rents from their new employer.

Several observations support this "rent extraction" perspective. First, a talent agent is often hired by the candidate CEO after a company has expressed interest in hiring the executive for the position of CEO. Hence, bargaining power in negotiation with the firm rests with the candidate CEO. Second, the agent may use other competing firms that are interested in hiring the candidate as a bargaining device to extract maximum compensation. Because the talent agent will often "shop" the candidate's services to multiple firms, the presence of the agent raises the opportunity cost of taking any one position, effectively endogenizing the executive's reservation wage. Third, some articles in the business press speculate that these agents charge a fixed percentage of the negotiated compensation package, making them even more like their counterparts in the sports and entertainment fields, who typically command anywhere from 7 to 20 percent of their clients' salaries (National Law Journal 1997, Chief Executive 2001). Tying the agent's compensation to that of the CEO provides incentives for the agent to negotiate generous pay packages. Finally, Malmendier and Tate (2008) find that the hiring of prestigious sought-after CEOs is often associated with inferior future operating and stock performance.

In contrast to the claims of rent extraction, it is plausible that the pay packages negotiated by the talent agent are consistent with a premium for CEO talent, i.e., efficient contracting. That is, it is possible that CEOs who use talent agents to negotiate their compensation packages, are in fact more talented than 
their peers (i.e. the use of a talent agent signals skill). The fact that $81 \%$ of the CEOs represented by talent agents (in our dataset) are hired from outside the firm supports this alternative perspective. ${ }^{2,3}$

Despite the controversial role played by talent agents in determining the terms of CEO employment and compensation, academic scrutiny of their involvement is surprisingly absent in the literature. In this paper, we examine two related questions: (i) Is there evidence that CEOs who use talent agents (hereafter, Client CEOs) are able to obtain “excess" pay?, (ii) If so, does this premium reflect rent extraction (as argued by Jensen et al., 2004) or compensation for the CEO's talent (or a signal of CEO's skills) ${ }^{4}$

To examine differences in compensation we benchmark the treatment sample (Client CEOs) with two different control samples: (i) a broad control sample of CEOs who do not use agents and, (ii) a propensity score matched control sample. Our results indicate that first year pay, composed of salary, bonus, and other equity grants, of CEOs who used a talent agent is higher by about $\$ 10$ million after controlling for economic, governance, and reservation wage determinants. However, significant differences in pay are constrained to the first year. To further investigate whether such "excess" compensation is indeed rent extraction or a manifestation of a higher level of equity incentives granted to increase the firm's stock price, we examine variation in sensitivity of the CEO's equity portfolio to a $1 \%$ change in stock price (portfolio delta). We find that CEOs who use a talent agent have significantly

\footnotetext{
${ }^{2}$ Since at most one of the firms interested in hiring the CEO can be the current employer, the observation that most CEOs represented by talent agents are hired from outside the firm is consistent with talent agents lining up multiple firms interested in hiring the candidate CEO.

${ }^{3}$ Approximately $40 \%$ of CEOs in our sample who used talent agents have employment contracts that contain an explicit make-whole arrangement whereby the new employer must reimburse the CEO for stock-options or other perquisites forfeited on departure from the prior employer.

${ }^{4}$ We consider rent extraction to consist of (i) "excess" compensation or an unexplained decrease in performance sensitive pay relative to a control sample after controlling for the standard set of economic, governance, and reservation wage determinants; and (ii) absence of superior future performance in the firm run by the new CEO. We also define a nuanced version of rent extraction labeled "economically significant rent extraction" as a state jointly characterized by both rent extraction and the destruction of shareholder wealth. Most studies (exceptions include Core et al. 1999) use excess compensation as a measure of rent extraction. We take a broader perspective that any model that determines excess compensation can never completely control for economic determinants of differences in compensation contracts. That is the reason we impose an additional necessary condition, i.e., lack of future performance, to demonstrate rent extraction. By excess compensation, we mean compensation in excess of the standard (economic and governance) determinants of pay, but not in excess of the CEO's talent.
} 
higher portfolio deltas relative to both control samples, inconsistent with the rent extraction view and consistent with differences in pay resulting from superior performance on the part of client CEOs.

We conduct two additional tests to examine whether the observed "excess" compensation represents economically significant rent extraction or compensation for talent. First, we examine whether firms that hire Client CEOs report inferior or superior future performance. We find that firms which hire Client CEOs outperform their control counterparts in two respects: (i) superior operating performance over the following three years; and (ii) positive abnormal stock returns over the following twelve months. Second, we examine whether the market perceives Client CEOs as being associated with inferior or superior future performance. Specifically, we consider the five day stock price reactions surrounding the appointment of Client CEOs. We find that abnormal returns are positive and both statistically and economically significant. Further, the returns are significantly greater than that obtained for their control counterparts. This evidence is consistent with investors revising their expectation about future firm performance upward for Client CEOs, both in an absolute and a relative sense. Collectively, our evidence is inconsistent with the assertions that Client CEOs extract rents from the firm. Rather, it is consistent with observed "excess" compensation representing a premium for CEO talent, and is consistent with the hypothesis that highly skilled CEOs retain talent agents to signal their ability.

Our paper contributes to the extant literature in several ways. Our paper is among the first to provide empirical evidence on the role played by third-party intermediaries in the CEO pay setting process. In addition, our paper contributes to the ongoing debate on whether CEO compensation practices, and specifically the presence of third-party intermediaries, is characterized by efficient contracting or rent extraction (e.g., Bebchuk and Fried 2004; Jensen et al. 2004; Conyon et al. 2006; Murphy and Sandino 2008; Armstrong et al. 2009a; Cadman et al. 2009). It may not be surprising that incoming CEOs represented by talent agents generally fare better in terms of compensation. However, the surprising finding to us is that, contrary to claims of rent extraction, we document that such CEOs are associated with superior future operating and stock performance. This is in contrast to Malmendier and 
Tate (2008) who find that prestigious sought-after CEO's are associated with inferior future operating and stock performance.

Additionally, our findings that the cross-sectional variation in first-year pay is largely influenced by the CEO's reservation wage (as opposed to economic determinants) and that the properties of firstyear pay are significantly different from ongoing pay have important implications for future research. First, our evidence suggests that proxies for the CEO's reservation wage are empirically important determinants of executive pay that are currently overlooked in the empirical literature. Second, because reservation wage determinants appear most important in explaining first-year pay, future research may want to consider first-year pay and ongoing pay separately rather than treating them as homogeneous.

The remainder of the paper is organized as follows. Section 2 discusses the role of talent agents in general, and describes the hypotheses tested in the paper. Section 3 introduces the talent agents examined in the study, discusses the research methods and control samples, and presents data on the sample. Section 4 documents the excess compensation and differences in performance sensitive pay associated with the use of talent agents. Section 5 discusses tests designed to assess the future performance of firms who hire a CEO represented by a talent agent. Section 6 presents some concluding remarks.

\subsection{Institutional Background and Hypotheses}

\subsection{Role of the talent agent}

Third-parties have perhaps always been involved in negotiating terms of CEO employment agreements. The use of legal counsel to help design and verify employment contracts is perhaps not a recent phenomenon. However, the services provided by talent agents are quite different from what is typically considered legal counsel. Traditional lawyers tend to focus on the legality and enforceability of an employment contract whereas talent agents are directly involved in the CEO placement process and negotiation of the financial terms of the contract. Talent agents not only negotiate the terms of the CEO's contract, but they also secure alternative opportunities in order to create competition for executive talent 
and gain a bargaining advantage. As such, talent agents are similar to corporate headhunters or executive search firms, except that they work for the CEO and search for potential employers, not employees. ${ }^{5}$

A review of the literature (both academic and the legal/business press) suggests that the advent of talent agents in the CEO labor market can be traced to four trends. First, the increased mergers and acquisition (M\&A) activity during the 1970s fueled demand for outside CEO succession and in turn, representation for external CEOs (Duch 1997). Much of the early literature assumes that CEOs are hired from the firm's internal labor market although recent empirical work suggests that (i) the frequency of forced turnover and outside succession has increased in the mid 1990s relative to the early 1970s (Huson, Parrino and Starks 2001); and (ii) at least one-third of all CEO successions in large publicly held firms are outsider successions (Khurana 2002). This trend creates a demand for corporate headhunters, who in turn, often recommend that the incoming CEO hire an agent for representation (Whitford 1998). Second, Hermalin (2005) reports that CEO tenure in the United States has fallen over time. Hence, CEO candidates may be reluctant to leave a position of relative security without a commensurate reward or a guarantee of protection if things don't work out with the new employer. Talent agents are arguably in a better position to negotiate such protection from the prospective employers and line up alternative employers. Third, the bullish stock market of recent years has had a direct influence on the size of the executive pay packages. This, in turn, increased the stakes causing a demand shock for talent agents (Duch 1997). Fourth, another contributing factor to the use of talent agents is the rise of the CEO to prominence in the media and a desire/need to manage this public image (Hayward et al., 2004; Chatterjee and Hambrick, 2006; Malmendier and Tate 2008).

\footnotetext{
${ }^{5}$ To the extent that these individuals provide services similar to traditional lawyers, we would expect to see similar compensation and firm outcomes after controlling for observables. Since we present empirical evidence that CEOs represented by these agents are able to extract higher compensation later in the paper, we view our findings as evidence that services provided by these agents differs from what is often associated with traditional lawyers. For our analyses, we take the distinct role of talent agents as given and proceed to investigate whether their involvement is associated with rent extraction.
} 


\subsection{Rent extraction hypothesis}

Whether executive labor markets are characterized by rent extraction or efficient contracting is an ongoing debate in the literature. Several prior studies interpret their findings as evidence of rent extraction in the CEO labor market. Both Core et al. (1999) and Faleye (2007) find an overall negative association between governance and "excess" pay, and document that such pay is associated with value destruction vis-a-vis poor future performance. Additionally, several recent studies argue that the involvement of third-parties in the pay setting process is associated with rent extraction. In particular, recent work by Conyon et al. (2006), Murphy and Sandino (2008), and Armstrong et al. (2009a) suggests that the increased pay levels associated with the use of compensation consultants is consistent with rent extraction. If compensation consultants who work on behalf of the Board are associated with rent extraction, then it is reasonable to believe that talent agents, whose interests are better aligned with the CEO's, are also associated with rent extraction.

Proponents of the rent extraction hypothesis (e.g., Jensen et al. 2004) argue that talent agents serve as a conduit for rent extraction by CEOs. They assert that the presence of the talent agent can provide CEOs with increased bargaining power that they can then exercise to extract favorable terms. For example, Jensen et al. (2004) report that at most times the incoming CEO negotiates not with the compensation committee, but with the general counsel of the firm or an executive such as the VP of Human Resources who will end up reporting to the CEO. Consequently, these executives have obvious incentives to please their new boss by being generous with the financial arrangements in the negotiation process. Jensen et al. (2004) quote the following passage to illustrate the negotiation process:

Mr. Bachelder takes private delight in spotting the other side's weaknesses during negotiations. "Joe took me aside after one contract," says Michael Valentino, an executive who has worked at several drug companies, and told me: 'I knew on Day One that we were going to get you everything you wanted.' When Mr. Valentino asked why, Mr. Bachelder told him that the hiring company had mistakenly put its general counsel in charge of the talks. "When this is over, you're going to be that guy's boss," Mr. Bachelder explained. "He knows that. He can't fight you too hard on anything." 
Moreover, Jensen et al. (2004) claim that the courting firm, not the incoming CEO, pays the agent's fees. ${ }^{6}$ Such a lop-sided negotiation process can be viewed as an agency problem where the incoming CEO has so much more bargaining power, vis-à-vis the directors of the company.

Fredman (2001) reports that the talent agent's specialized knowledge of CEO pay trends, contractual terms, and which firms are interested in hiring CEOs, is especially important because most negotiations between the candidate and the courting company are conducted at top speed. Hence, there is little time for the courting employer to thoroughly research comparable compensation packages and the candidate CEO's opportunity cost. Furthermore, it is alleged that talent agents are at a tactical advantage because by the time they get involved in negotiations, the board has decided on the candidate CEO and it is up to the agent to close the deal.

One may wonder how an executive (and his talent agent) who is not yet employed by the firm can co-opt the board and the governance process even before being hired. Proponents of the rent extraction hypothesis believe that co-opting can occur even with newly minted CEOs due to the potential bargaining power that the incoming CEO enjoys. Anders (2003) reports that CEO talent agents often arrive at a point of vulnerability for a corporation, when its board is hoping for a seamless change in leadership to steady the firm and chart a new course. The pressure from analysts, prominent institutional investors and even the media, to find and retain a CEO, especially for firms replacing a poorly performing CEO, can be quite high. This, in turn may result in "co-option" by the board to yield to the demands of a celebrity incoming CEO (as is the case with most of our sample) even though they may not have had sufficient history with the board of their new employer. It is plausible that the negotiation process is the beginning of what could be a broader failure in the governance process. In sum, the outcome of such a negotiation process can be an over-generous pay package and contractual terms of employment for the candidate CEO. Thus, our hypothesis is:

\footnotetext{
${ }^{6}$ Approximately $56 \%$ of CEOs in our sample who used talent agents have employment contracts that contain an explicit clause to this effect.
} 
$\mathrm{H}_{1}$ : The involvement of talent agents in the pay setting process is associated with rent extraction on the part of the CEO.

\subsection{Efficient contracting}

As with all rent extraction claims, the arguments underlying $\mathrm{H} 1$ are largely a-theoretic as they rely more on anecdotes rather than on solid theory. ${ }^{7}$ The alternative hypothesis to $\mathrm{H} 1$ is that either talent agents represent (i) an important information intermediary in the pay-setting process; and/or (ii) CEOs retain talent agents to signal their abilities. We hypothesize that the talent agent has superior knowledge, relative to the CEO, about the hiring firm. The "plain vanilla" principal agent model neglects the possibility of frictions in the CEO labor market such as the existence of non-trivial search costs for employees. Ex ante, talent agents play a role because their very existence suggests the existence of labor market frictions. If there were no market frictions, individuals would know who was hiring, know what the prospective employer was looking for, know their reservation wage and be able to negotiate with the employer and have no need for a talent agent or other representation. The talent agent is the one who does the job hunting for the CEO. The agent's job is to find out who is hiring, what they are looking forward, relay this to the CEO, and promote the CEO at the potential employer. Furthermore, CEOs may use talent agents to signal their (the CEOs) "high type.” If talent agents can credibly commit to working only with CEOs of high type, the high type CEOs will want to work with the agent in order to signal their talent to future employers, the talent agent need not contribution anything other than his seal of approval.

Talent agents can play a signaling role not unlike education in the Spence-model. If a talent agent has a reputation for working only with the CEOs of the highest ability, then high ability CEOs will want to work with this agent in order to credibly signal they are of high ability. The talent agent need not offer any service other than to stamp his seal of approval. These arguments suggest that the talent agent's involvement in the pay setting process need not necessarily be associated with rent extraction. In

\footnotetext{
${ }^{7} \mathrm{H}_{1}$ could be criticized on the grounds that it lacks theoretical justification. However, we take the approach of observing current practice in the executive labor market and ask what rational explanations have been offered in academe and the popular press to explain this practice. We then proceed to explore whether the practice is consistent with a rational explanation, and test the implications of this explanation.
} 
particular, differences in CEO pay between incoming CEOs with and without the involvement of a talent agent might merely reflect economic differences between firms and/or differences in CEO skill. Thus, the efficient contracting view posits that any differential compensation paid to CEOs that used a talent agent is explainable by economic determinants or superior talent. Thus, the efficient contracting view suggests:

$\mathrm{H}_{\mathrm{IA}}$ : The involvement of talent agents in the pay setting process is not associated with rent extraction. After controlling for economic determinants, differences in CEO pay between CEOs with and without talent agents represent premiums for the incoming CEO's talent.

\subsection{Sample and Descriptive Statistics}

\subsection{The agents}

To conduct our empirical analysis we first need to obtain a list of talent agents. We identified Joseph Bachelder and Robert Stucker as our initial set of agents. Several articles in the business press (e.g., Schellhardt 1998; Sachdev 2003) cite these two lawyers as leading agents. Besides these lawyers, we identified six others cited in an article in the National Law Journal (1997): David Anderson, Henry Blackiston, Lawrence Cagney, Linda Rappaport, Thomas Roberts and Jonathan Zorn. However, an extensive search of the SEC's EDGAR database, the employment contracts on The Corporate Library's database, LexisNexis, and Google resulted in seven usable sample observations for Lawrence Cagney but none for the other five. ${ }^{8}$ Hence, we restrict our attention to Bachelder, Stucker and Cagney.

Joseph E. Bachelder is an attorney based in New York City who has made his career negotiating employment contracts between large corporations and their senior executive management. He represents clients in matters related to both initial employment and severance. On his firm's website, www.jebachelder.com, Bachelder indicates that he has represented executives in matters involving several prominent companies such as AT\&T, Bank of America, Campbell Soup Company, Gillette, IBM, Morgan Stanley, Philip Morris, Sunbeam, and others. Bachelder has represented executives in contract

${ }^{8}$ Details on sample formation appear in Section 3.2 and Table 1. 
negotiations since 1980 and is reputed to be a hard-nosed negotiator (Anders 2003). He is also known to employ highly sophisticated methods to secure the most favorable terms for his clients. For example, he employs a mathematician who helps calculate the value of executive benefits such as forfeited pensions and option grants from the CEO's previous employer (Anders 2003). Such calculations enable Bachelder to ask the candidate CEO's new employer to "make whole" these forfeited benefits. Bachelder is also a public advocate of the high compensation levels currently paid to senior executives. While testifying before Congress in 2003, Bachelder rallied to chief executives' defense, portraying them as "fiduciaries of enormous masses of capital whose pay is set equitably in a free market."

Robert J. Stucker, often portrayed as Bachelder's leading competitor, is the chairman of the law firm Vedder Price Kaufman \& Kammholz and is nationally recognized as a tough negotiator in the recruitment and employment arrangements for CEOs. His resume posted on the law firm's website (www.vedderprice.com) lists assignments in the area of new CEO compensation and employment arrangements at companies such as Albertson's, Cable \& Wireless, Campbell's Soup, Delta Air Lines, Electronic Data Systems, Hershey Foods, Home Depot, Honeywell International, J.C. Penney, Levi Strauss, Mattel, 3M, Pharmacia, Quaker Oats, R.R. Donnelley, Tyco, The Gap, and SPX Corporation. Lawrence Cagney is a partner at Debevoise and Plimpton LLC (www.debevoise.com) and chairs the firm's Executive Compensation and Employee Benefits Group. His clients include executives placed at Disney, American Airlines, Chrysler, Hilton Hotels, and Starwood Hotels. Both Chambers USA (2005) and The Best Lawyers In America (2005- 2006, 2007) rank Cagney as a leader in employee benefits and executive compensation law.

We do not claim that the three talent agents we consider in this analysis are the only talent agents used by CEOs. Our intention is to focus on the most prominent talent agents employed by CEOs. We acknowledge that our sample of talent agents is small because the media coverage of less popularized agents, on which we rely to pick our sample of talent agents, is likely spotty or absent. Moreover, clientlawyer confidential agreements preclude obtaining an exhaustive list of talent agents and the CEOs who employ them. 


\subsection{Treatment sample}

Our treatment sample is comprised of incoming CEOs who have retained a talent agent to negotiate their employment contract. ${ }^{9}$ As mentioned before, our ability to identify these CEOs is limited, as client identity is covered by attorney-client confidentiality. To obtain our treatment sample we search the SEC's EDGAR database, the Corporate Library's database of employment agreements, LexisNexis, and Google for various permutations of the agent's name. This search results in several popular press articles that reveal details on certain talent agent clients, and actual employment agreements where the agent is mentioned as having represented the CEO. From here we are able to compile a list of executivefirm combinations that compose our client list (treatment sample). Panel A Table 1 reveals that of the 36 treatment firms identified, 13 were identified in employment agreements on file with the Corporate Library, 11 from SEC EDGAR filings, and 12 from LexisNexis and Google press articles. For a CEO to be part of our sample we require any two of three items: year of agreement, firm name, or executive name. This search process results in a list of 124 unique firms, which used one of the agents in at least one transaction (including those not involving executive compensation). Of these, we are able to identify CEO compensation agreements and the respective executives in 48 firms. ${ }^{10}$ We eliminate 14 firms because of data- availability constraints highlighted in panel A of Table 1. Panel B of Table 1 lists the names of the CEOs (along with the hiring firm) considered in our empirical analyses. Note that the courting firms are very prominent firms, as evidenced by the fact that the market capitalization of these

\footnotetext{
${ }^{9}$ Talent agents are also known to have negotiated termination agreements for CEOs when they leave their former employer (Fredman 2001). Note that these deals are different from severance agreements negotiated ex ante before the CEO joins the firm. A search for such ex post termination agreements yielded 14 observations. Apart from one case (Dick Grasso for NYSE), the other 13 represent CEO terminations at public firms. We did not investigate ex post terminations, but focused instead on talent agent involvement in incoming CEO negotiations for two reasons. First, termination payments are not captured by the EXECUCOMP database. While hand collecting such data for the treatment sample (talent agent clients) should be trivial, hand gathering termination data for a credible control sample of CEO terminations not negotiated by talent agent is likely to be a time-consuming and expensive venture (see Yermack 2006 for a discussion on severance packages). Second, even if we do find excess severance benefits for talent agent clients it would be very difficult to test whether such excess is consistent with value destruction. This is because any future firm performance that we examine subsequent to severance would be contaminated by the performance attributable to the incoming CEO.

${ }^{10}$ Our client identification procedure is designed to minimize instances where executives are falsely classified as having used a talent agent (i.e. we require explicit documentation either in a popular press article or in an employment contract). So we can rule out having misclassified executives as having used an agent when in fact they did not.
} 
firms in the year prior to hiring the incoming CEO constitutes $15.45 \%$ of the market capitalizations of Dow Jones industrial index and approximately $5 \%$ of the total market capitalization of the S\&P 500 .

Two potential concerns about sample selection bias deserve discussion. One, the talent agent may reveal his involvement to the press only in cases where the sample outcome was good for the agent, resulting in higher pay for the CEO, and hence tilting the sample toward rent extraction hypothesis (e.g., Jensen et al., 2004). However, it seems unlikely that a CEO or the firm would want to willingly provide information about potential rent extraction to outside stakeholders. A second concern is that the sample is potentially tilted in favor of the efficient contracting hypothesis in that firms potentially disclose the involvement of a talent agent when the incoming CEO is associated with superior future stock returns and operating performance (e.g., Laksmana 2008). However, because the disclosure of an agent is provided in the employment agreement, and is usually made at the time of hiring, this argument presumes (i) that the firm has ex ante knowledge about future returns and operating performance under the new $\mathrm{CEO}$, and (ii) that this knowledge is not impounded in price at the time of the disclosure (see Section 5.2). Thus, we do not believe that the sample is biased towards either finding rent extraction or efficient contracting.

\subsection{Control samples}

We investigate whether talent agents are associated with rent extraction using two approaches: (i) a traditional regression approach with an unmatched control sample and, (ii) a matched sample approach with a propensity score matched control sample. We use both methods to ensure robustness of our findings. Below we discuss the two approaches and construction of the two control samples.

\subsubsection{Regression Approach - Unmatched Control Sample}

We begin by examining how a non-randomly distributed treatment (the use of a talent agent) affects executive and firm outcomes. A common research design for investigating the effects of a treatment (or event) on outcome variables is to regress observed outcomes for all observations on an indicator variable for whether the observation received the treatment (Talent Agent) and to control for confounding effects by including such variables in the regression. 
The unmatched sample used in our regression analysis includes all CEOs on Execucomp excluding co-CEOs, with non-missing CEO appointment date, total compensation, total cash compensation, salary, restricted stock grants, and data on options values. Additionally, we require financial statement variables that we obtain from Compustat and governance variables obtained from Execucomp. Finally, we require that our sample contains data for the executive's first year as CEO of the firm. ${ }^{11}$ The resulting unmatched control sample contains 1,761 executives. ${ }^{12}$ To be clear, our unmatched sample consists of every firm that has a new incoming CEO on Execucomp and not identified as having used a talent agent. If we incorrectly classify executives as not having used a talent agent when in fact they did, this would bias toward finding similar results for both treatment and control groups.

Table 2 presents descriptive statistics for the treatment and unmatched control samples. We examine differences between the two samples on various dimensions such as firm characteristics, governance variables, reservation wage variables and compensation. Across all dimensions, we observe differences between the treatment and the control samples. First, treatment firms are larger in size and are less likely to separate the position of CEO and Chairman. Second, the treatment sample contains a larger fraction of CEOs who were hired from outside the firm (Outsider), who held the position of CEO at their previous employer (CEO of Prior Employer), and who worked in the same industry in their previous

\footnotetext{
${ }^{11}$ This is done to ensure comparability between results of tests on first-year pay and ongoing pay. In instances where firms in the treatment sample firms are missing data items in Compustat or Execucomp we hand collect it from the respective financial statements. A potential concern about compensation relates to partial-year employment. That is, a new CEO hiring a talent agent may have worked for a firm for three months in their first tenure year while another firm may employ the new CEO for nine months of the first tenure year. In un-tabulated results we find that the average months worked during the first year is the same between talent agent clients and non-talent agent clients. In addition, we annualized the cash compensation paid to the CEO in the first year to compensate for cross-sectional differences in the number of months worked in the first year and find similar results. ${ }^{12}$ To analyze future operating and stock performance following the hiring of the CEO, we impose additional sample constraints. In our analysis of future operating performance, we require ROA in the year after the CEO was hired, and in our analysis of future stock returns (event returns) we require coverage on CRSP over a 48-month (11-day) window centered on the date the executive became CEO. Thus, the analysis of future operating performance, stock performance, and event returns is based on samples of 1666, 1797, and 1794 observations respectively. We do not impose these sample requirements when analyzing contemporaneous executive compensation, as requiring future returns or operating performance would unnecessarily induce look-ahead or delisting bias.
} 
position (Industry Knowledge). ${ }^{13}$ Finally, we find that the unconditional average first-year pay of CEOs in the treatment sample is approximately $\$ 14$ million more than the control sample. Given these differences it is imperative that the relevant variables be included in the regression equation to control for confounding effects.

Despite controlling for the confounding effects, a natural concern with unmatched regressionbased approaches is the effect of omitted variables on the coefficient of interest, in this case the coefficient on Talent Agent. In order to call into question our collective evidence that the use of a talent agent is a proxy for unobserved talent, an omitted variable, unrelated to talent, would need to be not only positively related to compensation and equity incentives, but also to future operating performance, future stock performance, and event returns surrounding the appointment of the CEO, and incremental to existing control variables. While we view it as unlikely that omitted variable(s) would explain the collective results of our compensation, equity incentive, future operating performance, future stock performance, and event return tests, we can not rule out such a scenario.

\subsubsection{Matched Sample Approach - Propensity Score Matched Control Sample}

An inherent limitation with a traditional regression approach using an unmatched control sample is that such regressions assume a precise functional form of the outcome variable (e.g., compensation, operating performance, returns). In other words, the regression approach assumes that outcomes $(Y)$ are linear in observable predictors $(X)$. If instead outcomes are a non-linear function of $X$ or a linear function of non-linear transformations of $X$ (e.g. squared-term, interaction term, log transform), then simply regressing $Y$ on $X$ will not control for cross-sectional variation in observables between treatment and control samples. To see this, suppose there are two firms, firm 1 (2) is in the treatment (control) sample, and

$$
Y_{i}=\alpha_{i}+f\left(X_{i}\right) \quad i=1,2
$$

\footnotetext{
${ }^{13}$ Given the preponderance of external hires in the treatment sample, our matched sample in Table 1B is composed only of external hires.
} 
where $X_{\mathrm{i}}$ is the vector of observables for firm $i$ and $f($.$) is a non-linear function that maps observables to$ outcomes. Then the difference between $Y_{1}$ and $Y_{2}$ is not linear in the observables, such that a simple regression of outcomes on predictors will not adequately control for cross-sectional differences in observables across the two samples. To see this note that

$$
\begin{aligned}
Y_{1}-Y_{2} & =\alpha_{1}-\alpha_{2}+f\left(X_{1}\right)-f\left(X_{2}\right) \\
& \neq \alpha_{1}-\alpha_{2}+\beta\left(X_{1}-X_{2}\right)
\end{aligned}
$$

Because in general $X_{1} \neq X_{2}$, and we are not willing to assume a particular function form for the outcome, the latter $f($.$) terms will not cancel and, absent additional assumptions, we are left without an estimable$ function.

An alternative research design is to use a matched sample. In contrast to the regression-based approach, matching does not require the researcher to specify the functional form of the outcome being estimated, such that matching on observable predictors is robust to alternative (non-linear) functional forms of the outcome variable. The main difference between regression and matching approaches is how they incorporate confounding variables into the analysis. In a matched pair design, each observation that received the treatment effect is paired with an observation that did not receive the treatment but is similar along all other relevant dimensions. Since the matched control sample is similar in every observable dimension, any difference in outcome between treatment and control samples can be attributed to the treatment effect. Using the above framework, if we select firm 1 and firm 2 such that $X_{1}$ and $X_{2}$ are similar, $f\left(X_{1}\right)-f\left(X_{2}\right)$ goes to zero and we are left with:

$$
Y_{1}-Y_{2}=\alpha_{1}-\alpha_{2}+f\left(X_{1}\right)-f\left(X_{2}\right)=\alpha_{1}-\alpha_{2}
$$

Such that if firms are adequately matched along the relevant dimensions $(X)$, then to assess the treatment effect we need only compare the difference in outcomes across the two samples and no additional regression is necessary. This discussion suggests that an important step when using matching methods is to ensure covariate balance between the two samples, namely that both the treatment and control samples appear similar along all the relevant dimensions. 
Because of the many confounding covariates, we adopt the propensity score method for matching on multiple covariates (Rosenbaum and Rubin 1983; Armstrong et al. 2009b). The propensity score method is a simple way of matching on multiple dimensions simultaneously. In this approach, we determine a propensity score which is the conditional probability of receiving the treatment effect (i.e., the probability that the CEO used a talent agent) given all the observable confounding variables.

The propensity score method requires an estimate of the conditional probability of using a talent agent given observable economic, governance, and reservation wage determinants. We estimate a probit model that relates the probability of using a talent agent with various proxies of observable firm and CEO characteristics. We describe the various proxies below:

(i) Economic determinants: Based on prior empirical and theoretical research we include proxies for size - $\log ($ Sales), firm performance - ROA (return on assets) and RET (fiscal year buy-and-hold return), risk - Std Dev of ROA (Std Dev of RET), the standard deviation of ROA (RET) over the prior five fiscal years, investment opportunities - Investment Opp, the average fiscal year-end market-to-book ratio for the prior five years, and firm distress - Altman-Z.

(ii) Governance determinants: We include the following proxies for the firm's governance structure: (a) the extent of institutional ownership (Institutional Holdings); (b) whether the CEO is also the chair of the board (IsChair); (c); whether the CEO is interlocked with a member of the compensation committee (Interlocked); (d) the proportion of the top 5 highlycompensated officers of the firm that sit on the board (Top5Directors); (e) the proportion of the top 5 highly-compensated officers of the firm that are interlocked with the board members of the firm (Top5Interlocked); and (f) the fraction of the firm's equity owned by the top 5 highly-compensated officers of the firm (Top5Ownership). ${ }^{14}$

\footnotetext{
${ }^{14}$ One could argue that the governance determinants relate more to the relationship between the outgoing CEO and the board. However if there were agency problems at the firm which led to inflated compensation, prior to the hiring of the new CEO, these same agency problems might lead to inflated compensation being paid to the incoming CEO. Note also, that this concern only applies to the analysis of "first year pay." The ongoing pay of the CEO will be determined by governance structures as they evolve after the hiring of the new CEO. For this reason, we follow
} 
(iii) Reservation wage determinants: We use several proxies for the CEO's opportunity cost: (a) whether the CEO was hired from outside the firm (Outsider); (b) whether the CEO held the same position with his/her prior employer (CEO of Prior Employer); (c) whether the CEO has industry knowledge (Industry Knowledge), based on whether he came from the same Fama and French (1997) industry group; and (d) average total compensation for CEOs joining the respective Fama and French (1997) industry group that year, or Market Wage. As an aside, it is worth noting that the Market Wage variable implicitly controls for average compensation levels that are correlated with time and industry membership. Hence, the specifications to follow do not include explicit year and industry dummies. ${ }^{15}$

Panel A of Table 3 reports the results of estimating the propensity score model that incorporates the above variables, where the dependent variable (Talent Agent) is set to 1 if the CEO used a talent agent and is set to zero otherwise. We report results in a sequential manner by including economic, governance and reservation wage determinants additively one at a time. This helps illustrate the incremental explanatory power of each of the determinants in the probit estimation. Notice that the explanatory power (Pseudo $\mathrm{R}^{2}$ ) increases from $5.85 \%$ to $12.70 \%$ after including the governance determinants. Including the reservation wage determinants further increases the explanatory power to $23.12 \%$. Thus, all three determinants are important in the decision to use a talent agent. We restrict our attention to the full model (last two columns in Panel A of Table 3) that incorporates all the relevant firm and CEO characteristics and that has the best fit (highest $\chi^{2}$, highest Pseudo $\mathrm{R}^{2}$, and lowest AIC). The results suggest that use of a talent agent is more likely in larger firms (z-statistic on $\log ($ Sales) is 2.58), better performing firms (z-statistic on RET is 1.98), firms with low institutional ownership (z-statistic on Institutional Holdings is -2.70), firms that do not separate the CEO and

prior work and include governance as a determinant of compensation in our regressions, both for first-year and ongoing pay.

15 Ideally, we would have included the identity of the compensation consultant or the search agent as potential determinants of executive compensation. Note, however, that firms are required to disclose the identity of the compensation consultant only for years 2007 and beyond. We are not aware of systematic data on the involvement of search firms in hiring incoming CEOs. 
Chair positions (z-statistic on Is Chair is 2.44) and firms where a smaller proportion of the top 5 officers are interlocked (z-statistic of -3.21). Moreover, outside CEOs (z-statistic of 3.49), former CEOs (z-statistic of 1.74) and CEOs with a higher market wage (z-statistic of 1.74) are more likely to use talent agents.

We compute a propensity score, i.e., the predicted probability that the CEO used a talent agent, for each CEO, which we will use for constructing our matched pair. Unlike standard matching algorithms that match on specific variables in a step-wise fashion (for example, matching on size and then market-tobook), the propensity score procedure accommodates a large number of matching variables. The task of constructing a matched sample using stepwise matching becomes increasing difficult when treatment and control samples differ along several dimensions. Since we need to control for difference in economic factors, governance structure, and reservation wage, the propensity score methodology offers a parsimonious approach to obtaining a matched control sample. In particular, the Propensity Score Matched Sample is composed of the 36 CEOs known to have used a talent agent and the 36 CEOs not identified as having used talent agent but with the highest propensity scores.

An important step in the propensity score based matched sample is to evaluate covariate balance, i.e., determine the similarity in the distribution of the treatment and the propensity score matched control samples. Covariate balance ensures that the treatment and matched control sample are similar across all dimensions except the variable of interest, i.e., the use of talent agent. We assess covariate balance by testing whether the means (distributions) are different between the treatment and control samples and report $t$-statistics (Kolmogorov-Smirnov $p$-values) in Panel B of Table 3. The results suggest that the propensity score matched control sample resembles the treatment sample along virtually all dimensions. At the 5\% level the Kolmogorov-Smirnov test rejects the null of similar distributions in 2 of the 17 variables (note that at the 5\% level we might expect to reject at least one). Control firms differ in the distribution of Altman-Z and CEO of Prior Employer. Moreover, in cases where the two samples have dissimilar means, the differences mainly bias in favor of higher (lower) pay for the control (treatment) sample. Control sample firms are less likely to separate the position of CEO and Chair (control mean: 
0.83, treatment mean: $0.67, t$-statistic of -2.29 ), and the control sample contains a larger fraction of CEOs who were hired from outside the firm, in fact it is composed entirely of outside CEOs (control mean: 1.00 , treatment mean $0.81, t$-statistic of -2.80 ), and a larger fraction of CEOs who held the same position at their previous employer (control mean: 0.72, treatment mean: $0.33, t$-statistic of -3.17 ). On balance, we believe that we have a reasonable control sample that has reasonable covariate balance with the treatment sample.

\subsection{Compensation Analyses}

In this section, we examine both the entry (first-year) as well as subsequent pay packages of CEOs represented by talent agents relative to the unmatched control sample and the propensity score matched control sample.

\subsection{Do CEOs that use talent agents get more compensation than their counterparts?}

Initially, we consider first year compensation for CEOs. We do so because the dynamic nature of compensation contracts will make the compensation arrangements different across time. Surprisingly, most prior research simply pools first year compensation with subsequent compensation (e.g., Jensen and Murphy (1990), Sloan (1993), Hall and Murphy (2002), Engel et al. (2002), Roulstone (2003), Cheng (2004), Comprix and Muller (2006), and Core Guay Larcker (2008)). Column (1) of Table 4, Panel A presents the results of a regression of total CEO compensation for the treatment sample and the unmatched control sample on several firm-specific variables that are known to capture the economic determinants associated with pay. In particular, we use the following variables that are hypothesized by past research (Core et al. 1999) to determine compensation levels: size ( $\log ($ Sales $))$, investment opportunity set (Investment $O p p$ ), operating performance (ROA), stock performance (RET), and firm volatility proxied by standard deviation of ROA and stock returns (Std Dev of ROA, Std Dev of RET). Columns (2) and (3) estimate a similar regression using the governance proxies and proxies for 
reservation wage motivated in the previous section. ${ }^{16}$ Because pay is both cross-sectionally and serially correlated, t-statistics are based on standard errors clustered by firm and year (Gow et al., 2009; Petersen, 2009).

Consistent with prior work, column (1) shows that larger firms, firms with more volatile operating performance, and healthier firms pay their CEOs more (t-statistics on Log(Sales), Std. Dev. Of ROA, and Altman-Z are 7.18, 2.89, and 2.17 respectively). Note that ROA is not significant suggesting that the incoming CEO's first year pay is unrelated to his employer's ROA for the first year. More interesting, after controlling for the above variables, the presence of a talent agent adds $\$ 11.6$ million to a CEO's first year total compensation $(\mathrm{t}$-statistic $=5.53)$. Thus, it appears that talent agents are able to extract significant excess compensation for their client CEOs.

We next investigate whether the excess compensation attributable to talent agents is due to the presence of weak governance structures that CEOs exploit to extract greater compensation. Results in column (2) of Table 4, Panel A are mixed. There is some evidence to support the hypothesis that CEOs extract rents due to weak governance, i.e., firms with $\mathrm{CEO}$ as the chairman of the board and where a greater fraction of officers are interlocked. However, the proxies for governance structures are insufficient to eliminate excess compensation attributable to talent agents.

Turning to the proxies for reservation wage in column (3), we find that outside CEOs and CEOs with a higher market wage before they join the firm are paid more (t-statistics of 3.92 and 6.36 respectively), consistent with the predictions of Harris and Helfat (1997). Moreover, the reservation wage determinants have greater explanatory power than the economic determinants. In particular, the reservation wage determinants explain $27.44 \%$ of the variation in compensation of incoming CEOs relative to $20.17 \%$ attributable to the economic determinants. Thus, it appears as though the reservation wage is a key determinant of first year pay and potentially even more important than economic determinants and governance proxies. In untabulated work, we have added four additional variables to

\footnotetext{
${ }^{16}$ Note that the variables used to construct the propensity score matched sample are also the variables used to estimate expected pay by design not by accident. Recall that our matched sample design requires us to match on all relevant predictors of the outcomes of interest.
} 
proxy for the incoming CEO's reservation wage in the regression of first year pay on reservation wage proxies without any change in the reported inferences: (a) stock return performance at the new CEO's prior firm over the last three years of his tenure; and (b) incoming CEO's total compensation for the last year at his previous firm to account for the pay given up at the prior employer; (c) value of unexercisable in-the-money options for the incoming CEO during the CEO's last year at his previous firm; and (d) the celebrity status of the CEO, proxied by the number of mentions in the popular press.

In column (4) of Table 4, Panel A we report results from the regression after including all the determinants of CEO compensation. We find that most of the determinants that are significant in regressions reported in columns (1) through (3) are also significant in the regression reported in column (4) with one exception. The only governance proxy that survives the economic determinants introduced in column (4) is Top5Interlocked ( $\mathrm{t}$-statistic $=2.17$ ). Thus, firms where a bigger proportion of the officers are interlocked appear to pay their incoming CEOs more.

While a significant portion of the compensation of CEOs is attributable to economic determinants, governance structures and higher reservation wages, we still observe that $\$ 10.3$ million of "excess" compensation attributable to talent agents remains unexplained. ${ }^{17}$ Much of the excess compensation stems from equity compensation rather than from cash compensation (see columns (5) and (6) of Table 4, Panel A).

When we benchmark the compensation of the treatment firms with propensity-score matched control firms, the differences in "excess" compensation persist. Recall that the control sample is empirically similar to the treatment sample along all the relevant dimensions. Panel B of Table 4 shows that the average (median) total compensation for treatment sample CEOs is $\$ 17.7$ (\$11.3) million, relative to $\$ 8.3$ (\$3.2) million for control sample CEOs. The difference in means, medians, and distributions are statistically significant at less than at less than the $1 \%$ level.

\footnotetext{
${ }^{17}$ We also control for the capital market's perception of CEO talent by including the 11 day market reaction surrounding the announcement of a new CEO as a control variable in the regressions. While the coefficient on the announcement period return is significantly positive, inferences from untabulated results are qualitatively similar to those previously reported.
} 
Table 5 reports evidence on whether the excess compensation reported for first year persists in subsequent years after CEO appointment. We employ the same regressions specification as before, but restrict our analysis to those years subsequent to the year of appointment. In this manner, the coefficient on Talent Agent captures the average excess annual compensation for a CEO who used a talent agent in the years subsequent to appointment. The results are mixed. Results from the unmatched sample reported in panel A suggest that CEOs who hire a talent agent enjoy "excess" total compensation after the first year of about $\$ 2.7$ million (see column 4). This is significantly smaller than that reported for CEO's first year compensation.

However, we are unable to find any "excess" compensation associated with talent agents when we use the propensity matched control (see panel B of Table 5). Aggregating the evidence, we conclude that the effect of talent agents on the level of CEO pay is primarily in the CEO's first year of office.

\subsection{Equity incentives}

In this section we consider another approach to examine whether compensation contracts negotiated by talent agents represent rent extraction. We investigate whether the intensity of equity incentives given to executives to raise the firm's stock price is different between the treatment and control samples. Our measure of incentive intensity is the quintile rank of the change in the risk-neutral value of the CEO's equity portfolio for a $1 \%$ change in the price of the underlying stock. In other words, we use the CEO's Portfolio Delta as a measure of equity incentives. We use the quintile rank of Portfolio Delta in our analysis to reduce measurement error associated with computing the equity portfolio delta (Core and Guay 2002; Armstrong et al. 2009b). In particular, we use quintile ranks instead of the actual portfolio deltas because the distribution of the actual portfolio deltas is severely right skewed.

Regression results of estimating the relation between Portfolio Delta and the economic and governance factors outlined in the previous section are presented in panel A of Table 6. As before, we consider the equity incentives for the first year of CEO appointment as well as the equity incentives for years subsequent to the appointment. Panel A reveals that executives that use a talent agent are offered greater equity incentives when compared to the larger control sample, regardless of whether the first- 
year's incentives or longer period incentives are considered. The coefficient on Talent Agent is the same, 0.72 , for both first year and subsequent years.

When the propensity-score matched sample is considered, the average equity incentive for both the year of CEO appointment and subsequent years is larger for the treatment sample relative to the matched control sample. Collectively, the evidence suggests that a CEO who retains a talent agent gets greater incentives to increase the firm's stock price relative to the control sample. Such higher levels of ongoing incentives are generally consistent with the earlier observation that several talent agent clients are hired to turn ailing companies around. If CEOs use talent agents to signal skill and are truly more talented, then they would seek to have greater equity base pay as this allows for a greater pay-forperformance link and maximizes the potential payoff from superior firm performance. Hence, under the efficient contracting hypothesis, we would expect to observe greater equity/performance pay for CEOs that hire talent agents.

\subsection{Is the presence of talent agents associated with value destruction?}

The evidence thus far points to support for "excess" compensation as well as increased equity incentives in the year of appointment of talent agent CEO. However, it is quite plausible that the "excess" compensation and equity incentives may simply be indicative of efficient contracting. We turn next to an investigation of whether the presence of talent agents is associated with significant rent extraction. The efficient contracting view posits that the "excess" compensation documented earlier is compensation for talent, such that we would expect to find that the hiring of a talent agent CEO is associated with superior future operating and/or stock performance. In particular, superior future operating and/or stock performance would be consistent with the hypothesis that skilled CEOs retain talent agents to signal their skill. In contrast, the rent extraction view posits that the "excess" compensation is not attributable to talent and hence, the presence of talent agent should not increase future firm performance, and at the extreme (in the case of value destruction) result in inferior future operating and/or stock performance. 
To provide evidence on these two alternative explanations, we follow Core et al. (1999) to assess whether talent agent CEOs are associated with future operating and stock performance. Note the difference between these two performance measures. Using stock returns as a measure of future performance may result in lower power in discriminating between efficient contracting and rent extraction because a test based on stock returns is a joint test of stock market efficiency and contracting efficiency. For example, even if rent extraction were the true state of the world, investors in an efficient stock market might anticipate such rent extraction and already factor it into the existing stock price. As a result, future stock returns could be unrelated to the existence of the talent agent, even if they extract rents from the firm on behalf of their CEO clients. Thus, an examination of future stock returns, in isolation, cannot rule out rent extraction even if evidence supports otherwise. Earnings-based performance metrics such as ROA suffer less from the problem of anticipating rent extraction but have problems of their own. In particular, ROA is inherently backward looking and is hence likely to lag stock returns in information content. Moreover, incoming CEOs could take discretionary accounting decisions such as big-baths to manipulate future ROA. We hope that a combined analysis of these two performance measures can shed some light on whether the excess compensation for talent agent clients represents rent extraction.

\subsection{Talent agents and future operating performance}

Table 7 presents results related to a regression of future ROA, i.e., 1 year, 3 year and 5 year ahead $\left(R O A_{t+1}, R O A_{t+3}, R O A_{t+5}\right)$ on the Talent Agent indicator variable after controlling for standard determinants of future performance. In particular, we include a proxy for size $(\log (\operatorname{Sales}))$, standard deviation of ROA (Std Dev of ROA), proxy for investment opportunities (Investment Opp) and current ROA $(R O A)$. The coefficient on the indicator variable captures the incremental association between the talent agent $\mathrm{CEO}$ and future performance.

The results in panel A reveal a positive association between the talent agent indicator and future ROA for one and three years ahead. Results from the propensity score matched sample reported in panel B paint a similar picture. This suggests that firms that hire talent agent CEOs experience improved short 
run future operating performance. There is no evidence to suggest that the involvement of a talent agent is associated with lower operating performance.

\subsection{Talent agents and future stock performance}

Table 8 provides evidence on the association between talent agents and stock returns. In particular, we consider monthly returns (less the risk free rate) for the 24 months preceding and following the CEO appointment date regressed on the four factor Fama-French (1993) and Carhart (1997) model along with the talent agent indicator. We also interact the factor loadings with the talent agent indicator to allow risk loadings to vary by group membership. As before, panel A reports the regression results for the unmatched control sample whereas panel B reports results for the propensity score matched sample.

Column (3) of Table 8 suggests that the involvement of talent agents is associated with positive abnormal returns for the months 0 to 12 , regardless of whether the larger control group (panel A) or the propensity score matched sample is considered (panel B). ${ }^{18}$ However, the superior return performance is not seen after the $13^{\text {th }}$ month in either panel. Nevertheless, the positive abnormal returns from months 0 to 12 are inconsistent with talent agents extracting rents at the expense of shareholder wealth.

A closer look at the abnormal returns in months -24 to -13 prior to the new CEO hire suggests that firms in the talent agent group perform worse than the market (coefficient on Talent Agent is -1.49 , tstat is -2.89 ). However, this trailing under-performance weakens significantly when the propensity matched sample is considered (coefficient on talent agent is -1.14 , t-stat is -1.56 ; see Panel B). This pattern is consistent with allegations in Anders (2003) that talent agents like Bachelder often come on the scene at a point of vulnerability for a corporation, when its board is hoping for a cleanly executed leadership change to steady the firm and set a new course. It is also consistent with Warner et al. (1988) and Huson et al (2001), who find that the probability of a change in CEO is inversely related to past stock returns.

\footnotetext{
${ }^{18}$ Despite not explicitly matching on factor loadings, Panel B reports that, with the exception of the momentum factor, the factor loadings between treatment and matched control samples are not statistically different. This further validates that the matched control sample is similar to the treatment sample.
} 
In sum, the collective weight of the evidence presented in Tables 7 and 8 are consistent with the hypothesis that skilled CEOs retain talent agents to signal their skill. There is no evidence of rent extraction.

\subsection{Event study stock returns}

While we are unable to document any evidence of rent extraction after considering several alternative measures, it is useful to validate our findings by examining whether the capital market participants perceive the appointments of talent agent CEOs similarly. That is, we investigate whether investors price such appointments any differently than other CEO appointments. Therefore, in Table 9, we explore whether the short-window stock market reaction associated with the appointment of a talent agent CEO is significantly different from that of the unmatched control sample. We define the event day 0 as the date EXECUCOMP records as the day on which the executive became CEO (appointment date). If no trading occurs on the appointment date we define event day 0 as the next trading day. If the talent agent CEO is perceived by the stock market as extracting value-destroying rents from the firm, then assuming market efficiency, the rent extraction hypothesis predicts that the short-window stock market reaction is negative. In contrast, if the talent agent CEO is perceived as possessing superior talent and creating value, then assuming market efficiency, we predict that the short-window stock market reaction is positive.

There are several caveats associated with the short-window event analysis. First, the stock market might anticipate the need for a new CEO in both the control and treatment samples much before the new CEO is appointed. Hence, our short-window event study tests might suffer from low statistical

power. Second, it is unclear whether the stock market is aware of the involvement of talent agent in the contract negotiation process at the time a talent agent CEO takes office. Hence, attribution of the short window returns to rent extraction or efficient contracting will depend on the stock market's ability to predict the involvement of talent agent. However, these caveats are likely to bias against finding a differential reaction for the talent agent sample. 
Table 9 presents several versions of short-window buy and hold stock returns for the talent agent and the two control groups (unmatched and the propensity score matched sample) where (i) event windows vary from $(-5,+5)$ days to $(-1,+1)$ days surrounding the appointment; and (ii) stock returns of the sample firms are benchmarked against returns to the CRSP value-weighted index and that of a size matched portfolio. ${ }^{19}$ Benchmarking returns surrounding the hiring date of the incoming CEO where a talent agent is involved to the returns around the hiring date of the control firm's incoming CEO is important to rule out suggestions that the positive stock price reaction to a talent agent mediated CEO is attributable to the high opportunity cost of not having a CEO in place.

The results presented in Table 9 suggest, in general, that the market views appointments of CEOs represented by talent agent as value-increasing relative to the control group. For example, the difference between the market adjusted buy and hold return for the 11-day window surrounding the appointment of a talent agent CEO and the large control sample CEO is 5.58\% (t-statistic $=2.67)$. Similar results obtain when the event returns surrounding the appointment of talent agent CEOs are benchmarked against the appointment of CEOs in the propensity score matched control sample. The event study results, subject to the caveats enumerated in the previous paragraph, again buttress our earlier findings hat skilled CEOs retain talent agents to signal their skill premium for talent. These results do not support the rent extraction hypothesis. ${ }^{20}$

\footnotetext{
${ }^{19} \mathrm{We}$ also estimate average abnormal returns in addition to buy and hold abnormal returns and our inferences are unaffected.

${ }^{20}$ Combining results in Table 9 on event study returns and evidence of superior stock return performance in Table 5 , the reader might ask how one could reconcile positive abnormal returns associated with this superior CEO subsequent to the CEO's hiring date with the short-window positive returns around the CEO hiring date. We argue that even if the market knows that the incoming CEO hired a talent agent, the presence of such an agent represents an innovation, and the positive or negative performance consequences of this innovation become clear only with the passage of time. In this case, when there are improvements in subsequent operating performance, the market will be surprised and there will be positive abnormal returns for a period following the incoming CEO's hiring date. For example, the stock market might react to changes in managerial investment and financing decisions, rather than to the presence of the talent agent associated with the incoming CEO.
} 


\subsection{Conclusions}

The paper provides empirical evidence on the nature of CEO employment contracts signed when third party intermediaries are involved in negotiations between the candidate CEO and the firm. In particular, we find that when talent agents act on behalf of their client CEOs, the first year total compensation relative to a broad control sample is significantly higher by $\$ 10$ million even after controlling for the standard set of economic determinants of pay, proxies for governance quality and proxies for the incoming CEO's reservation wage. In addition, the talent agent CEOs also tend to have greater equity-based incentives to increase their firm's stock price relative to their control counterparts.

While at first blush such "excess" compensation generated by talent agents on behalf of their CEO client may hint at rent extraction, our subsequent investigation suggests otherwise. Specifically, we find a positive association between the involvement of talent agents and future operating and stock return performance of the hiring firm. Consistent with the market revising its expectations upward, we also find that the short-window (one or five day) market reaction surrounding the appointment of a talent agent CEO is positive and significantly higher, on average, than that for the appointment of control sample CEOs. Collectively the evidence suggests that the "excess" compensation paid to CEOs represented by talent agents is consistent with the hypothesis that skilled CEOs retain talent agents to signal their skill and is not consistent with rent extraction.

Our study is subject to two caveats. First, we have to caution the reader that demonstrating causality between the use of a talent agent and the CEO's compensation contract is problematic for two reasons. One, it is difficult for outside researchers to observe the negotiation process conducted by talent agent. Two, as many of the talent agents tend to be lawyers, attorney-client confidentiality provisions force us to rely on a small, perhaps atypical sample of CEOs who are known to have used a talent agent. Nevertheless, we hope to inform the current debate about excess CEO pay by demonstrating that although the contractual and compensation terms negotiated by talent agents may appear to be opportunistic at the expense of the firm, we observe superior operating and stock performance subsequent to the involvement of a talent agent in the CEO appointment process. Second, we acknowledge that the focus of the 
manuscript is limited because the mechanisms by which CEOs are selected and compensated are much more complex. In particular, our work suggests the need for more theoretical and empirical research on how third party intermediaries facilitate transactions in the CEO labor market. 


\section{References}

Anders, G. 2003. Upping the Ante: As Some Decry Lavish CEO Pay, Joe Bachelder Makers It Happen. Wall Street Journal. P. A1. June 25.

Armstrong, C., C. Ittner and D. Larcker. 2009a. Economic Characteristics, Corporate Governance, and the Influence of Compensation Consultants on Executive Pay Levels. Working paper, Stanford University.

Armstrong, C., A. Jagolinzer and D. Larcker. 2009b. Chief Executive Officer Equity Incentives and Accounting Irregularities. Journal of Accounting Research, forthcoming.

Bamber, L. J. Jian, and I. Wang. 2009. What's My Style? The Influence of Top Managers and Their Personal Backgrounds on Voluntary Corporate Financial Disclosure. Working Paper, University of Georgia.

Barro, J., B. Hall and A.Zimmerman. 2004. Joe Bachelder: Executive Pay Negotiator. Harvard Business School Case Study, November 4.

Bebchuk, L. and J. Fried. 2004. Pay Without Performance: The Unfulfilled Promise of Executive Remuneration. Harvard University Press.

The Best Lawyers In America. 2004. Woodward/White Inc., SC.

The Best Lawyers In America. 2005-6. Woodward/White Inc., SC.

Cadman, B. Carter, M.E., and S. Hillegeist. 2009. The Role and Effect of Compensation Consultants on CEO Pay. Journal of Accounting and Economics, forthcoming.

Carhart, M. 1997. On Persistence in Mutual Fund Performance. Journal of Finance 52: 57-82.

Chambers USA. 2005. Americas Leading Business Lawyers. Chambers and Partners, London.

Chatterjee, A. and D. Hambrick. 2007. It's All about Me: Narcissistic Chief Executive Officers and Their Effects on Company Strategy and Performance. Administrative Science Quarterly 52: 351-386.

Cheng.S. 2004. R\&D Expenditures and CEO Compensation. The Accounting Review 79(2): 305-328.

Comprix, J. and K.A. Muller III. 2006. Asymmetric Treatment of Reported Pension Expense and Inocme Amounts in CEO Cash Compensation Calculations. Journal of Accounting and Economics 42(3): 385-416.

Core, J. and W. Guay. 2002. Estimating the Value of Employee Stock Option Portfolios and Their Sensitivities to Price and Volatility. Journal of Accounting Research 40: 613-630.

Core, J., W. Guay, and D. Larcker. 2008. The Power of the Pen and Executive Compenstion. Journal of Financial Economics 88(1): 1-25.

Core, J., R. Holthausen and D. Larcker. 1999. Corporate Governance, CEO Compensation, and Firm Performance. Journal of Financial Economics 51:371-406. 
Duch, D.W. 1997. CEO Super-Agents. National Law Journal.

Dyreng, S., M. Hanlon and E. Maydew. 2009. The Effects of Executives on Corporate Tax Avoidance. The Accounting Review (forthcoming).

Engel, E., E.A. Gordon, and R.M. Hayes. 2002. The Roles of Performance Measures and Monitoring in Annual Governance Decisions in Entrepreneurial Firms. Journal of Accounting Research 40(2): 485-518.

Faleye, O. 2007. Classified Boards Firm Value, and Managerial Entrenchment. Journal of Financial Economics 83: 501-529.

Fama, E., and French, K. 1993. Common Risk Factors in the Returns on Stocks and Bonds. Journal of Financial Economics 33:3-56.

Fama, E., and K. French. 1997. Industry Costs of Equity. Journal of Financial Economics 43: 153-193.

Francis, J., A. Huang, S. Rajgopal, and A. Zang. 2008. CEO Reputation and Earnings Quality. Contemporary Accounting Research 25 (1): 109-147.

Fredman, C. 2001. Do You Need An Agent? As Turnover Mounts, More CEOs turn to Sports and Entertainment-style Negotiators. Chief Executive (November).

Ge, W., D. Matsumoto, and J. Zhang. 2008. Do CFOs Have Style of Their Own? An Empirical Investigation of the Effect of Individual CFOs on Financial Reporting Practices. Working Paper.

Gow, I., G. Ormazabal, and D. Taylor. 2009. Correcting for Cross-Sectional and Time-Series Dependence in Accounting Research. The Accounting Review (forthcoming).

Greene, W. 2003. Econometric Analysis. 5th edition. Macmillan Publishing Co.

Hall, B.J. and K.J. Murphy. 2002. Stock Options for Undiversified Executives. Journal of Accounting and Economics 33: 3-42.

Harris, D., and C. Helfat. 1997. Specificity of CEO Human Capital and Compensation. Strategic Management Journal 18: 895-920.

Hayward, M., V. Rindova, and T. Pollock. 2004. Believing One's Own Press: The Causes and Consequences of CEO Celebrity. Strategic Management Journal 25: 637-653.

Hermalin, B. 2005. Trends in Corporate Governance. Journal of Finance 60(5): 2351-2384.

Huson, M., R. Parrino and L.T. Starks. 2001. Internal Monitoring Mechanisms and CEO Turnover: A Long-Term Perspective. Journal of Finance 56(6): 2265-2297.

Jensen, M., and K. Murphy. 1990. Performance Pay and Top-Management Incentives. Journal of Finance 98 (2): 225-264.

Jensen, M., K. Murphy and E. Wruck. 2004. Remuneration: Where We've Been, How We Got to Here, What are the Problems, and How to Fix Them. Working paper, Harvard Business School. 
Kaplan, S., M. Klebanov, and M. Sorensen. 2007. Which CEO Characteristics and Abilities Matter? Working paper.

Khurana, R. 2002. Searching for a Corporate Savior: The Irrational Quest for Charismatic CEOs. Princeton University Press, 2002.

Laksmana, I. 2008. Corporate Board Governance and Voluntary Disclosure of Executive Compensation Practices. Contemporary Accounting Research 25 (4): 1147-1182.

Malmendier, U. and G. Tate. 2008. Superstar CEOs. Working Paper, University of California - Berkeley.

Murphy, K.J. and T. Sandino. 2008. Executive Pay and "Independent" Compensation Consultants. Working paper, University of Southern California.

Murphy, K.J., and J. Zabojnik. 2004. CEO Pay and Turnover: A Market Based Explanation for Recent Trends. American Economic Review (Papers and Proceedings), May.

National Law Journal. 1997. CEO Super-Agents, July 28, page A1.

Petersen, M. A. 2009. Estimating Standard Errors in Finance Panel Data Sets: Comparing Approaches. Review of Financial Studies 22 (1): 435-480.

Rosenbaum, P., and D. Rubin. 1983. The central role of the propensity score in observational studies for causal effects. Biometrika 70: $41-55$.

Roulstone, D. 2003. The Relation Between Insider-Trading Restrictions and Executive Compensation. Journal of Accounting Research Volume 41(3): 525-551.

Sachdev, A. 2003. Lawyers Help Executives Win Big Bucks from Major Corporations. Chicago Tribune, September 14.

Schellhardt, T.D. 1998. Executive Pay (A Special Report): Pay Checks. They Show them the Money: Lawyer-agents like Robert J. Stucker Help Executives Win the Big Bucks - and not Overlook the Fine Print. Wall Street Journal, R6.

Sloan, R. 1993. Accounting Earnings and Top Executive Compensation. Journal Accounting and Economics 16(1-3): 55-100.

Warner, J., R.Watts and K. Wruck.1988. Stock Prices and Top Management Changes. Journal of Financial Economics 20: 461-492.

Whitford, D. 1998. Becoming CEO? Call him first. Fortune, June 8 v137 n11 p281(2).

Yermack, D. 2006. Golden Handshakes: Separation Pay for Retired and Dismissed Executives. Journal of Accounting and Economics 41: 237-256. 


\section{Table 1. Sample Formation}

\section{Panel A. Treatment Sample Compilation}

In order to identify a CEO who retained one of the talent agents, we require any two of three items: year of agreement, firm name, or executive name. Since firms are required to file employment agreements with the SEC and the agent is often mentioned as the executive's representative, we search all SEC EDGAR filings for various permutations of the agent's name. The results are then searched for employment agreements. In addition we search all employment contracts on file at The Corporate Library for various permutations the agent's name. Lastly we search the LexisNexis Legal and Business News databases and Google for various permutations of the agent's name. The LexisNexis and Google search result in several popular press articles that give details of clients. Note that the identity of clients is covered under attorney-client confidentiality so compiling a client list from publicly available sources is necessary.

\begin{tabular}{|c|c|c|c|c|}
\hline Criteria & Bachelder & Stucker & Cagney & Total \\
\hline $\begin{array}{l}\text { Identified firms with transactions involving the } \\
\text { specified negotiator/lawyer }\end{array}$ & 73 & 41 & 10 & 124 \\
\hline Less: Unidentified Transactions: where firm is & & & & \\
\hline $\begin{array}{l}\text { known but not the executive or the type of } \\
\text { transaction }\end{array}$ & 28 & 8 & 0 & 36 \\
\hline Less: non-CEO employment agreements or where & & & & \\
\hline lawyer represented the firm & 21 & 17 & 3 & 41 \\
\hline $\begin{array}{l}\text { Identified transactions involving CEO employment } \\
\text { agreements }\end{array}$ & 24 & 16 & 7 & 47 \\
\hline $\begin{array}{l}\text { Less: transactions prior to } 1991 \text { where } \\
\text { compensation from EXECUCOMP and from firm } \\
\text { filings is not available }\end{array}$ & 1 & & 1 & 2 \\
\hline Less: Pre-IPO transactions & 1 & 1 & & 2 \\
\hline $\begin{array}{l}\text { Less: Private firm transactions: including those only } \\
\text { trading on OTCBB pink sheets or acquired during }\end{array}$ & & & & \\
\hline the year the CEO was hired & 5 & 1 & & 6 \\
\hline Less: Foreign firms & 1 & & & 1 \\
\hline Total clients in Treatment Sample & 16 & 14 & 6 & 36 \\
\hline $\begin{array}{l}\text { Percent where firm's name was referenced on the } \\
\text { lawyer's corporate webpage* }\end{array}$ & $43.75 \%$ & $53.85 \%$ & $0.00 \%$ & $41.18 \%$ \\
\hline Sources used for identification: & & & & \\
\hline Corporate Library & 13 & & & \\
\hline SEC EDGAR filings & 11 & & & \\
\hline LexisNexis press articles & 12 & & & \\
\hline
\end{tabular}

* The respective web pages only list firm names and by themselves do not provide enough information to identify the executive or the nature of the transaction 


\section{Panel B. Treatment Sample}

\begin{tabular}{ll|ll}
\hline Executive & Firm & Executive & Firm \\
\hline Lawrence Bossidy $^{\%}$ & Allied Signal/Honeywell & Bob Nardelli & Home Depot \\
Robert Eaton & Chrysler & David Schneider & Nextera \\
George Fisher & Eastman Kodak & Jamie Dimon & Bank One \\
Louis Gerstner & IBM & Michael Hammes & Sunrise Medical \\
Michael Jordan & Westinghouse/CBS & W.G. Jurgensen & Nationwide Insurance Company \\
Floyd Hall & K-Mart & Douglas Conant & Campbell Soup \\
John Blystone & SPX Corporation & James McNerney & 3M \\
Stephen Bollenbach & Hilton Hotels & Jay Sugarman & Istar Financial/Starwood Capital \\
Leo Mullin & Delta Airlines & John Edwardson & CDW computer centers \\
Michael Armstrong & AT\&T & Lawrence Johnston & Albertsons \\
Robert Morrison & Quaker Oats & Richard Lenny & Hershey Foods \\
Robert Iger & Disney & Steve Odland & Autozone \\
William Davis & R.R. Donnelley & David Cote & Honeywell \\
Gregory Andrew & Carson Inc & Patricia Russo & Lucent \\
Michael Hernandez & LifeMark & Ray Warrell & Genta \\
Richard Nanula & Starwood Hotels & Thomas Crocker & Koger Equity \\
Samuel Reed & Dean/Treehouse Foods & Peter Georgiopoulus & General Maritime \\
Richard Brown & EDS & Surya Mohapatra & Quest Diagnostics \\
\hline
\end{tabular}

${ }^{\%}$ Bossidy's contract was negotiated in the latter part of 1991 but for the sake of data availability we use his 1992 EXECUCOMP record.

${ }^{+}$Armstrong was a previous client of Bachelder, and while Bachelder represented the AT\&T board in negotiations with Armstrong, he did hand select the negotiator/lawyer Sam Butler, who represented Armstrong.

${ }^{\&}$ While not flagged as a CEO by EXECUCOMP, Nanula was appointed CEO of Starwood Hotels Worldwide on 4/18/98 the publicly traded portion of the paired-share REIT Starwood Hotels and Resorts. Nanula resigned in 1999 when Starwood reorganized as a standard ' $C$ ' corporation and was not appointed CEO of the resulting firm.

\# Sugarman, Warrell, and Crocker were all identified as having used a negotiator to re-negotiate their employment terms. We were unable to find any evidence that a negotiator was used in the initial employment agreement. For these executives we treat the date of the renegotiated contract as the date the respective executive became $\mathrm{CEO}$. 
Table 2. Descriptive Statistics

\begin{tabular}{|c|c|c|c|c|c|c|}
\hline \multirow[b]{2}{*}{ Variable } & \multicolumn{2}{|c|}{ Treatment Sample } & \multicolumn{2}{|c|}{$\begin{array}{c}\text { Unmatched } \\
\text { Control Sample }\end{array}$} & \multirow{2}{*}{$\begin{array}{l}\text { Diff in } \\
\text { Means } \\
\text { t-stat. }\end{array}$} & \multirow{2}{*}{$\begin{array}{c}\text { KS } \\
\text { p-value }\end{array}$} \\
\hline & Mean & Median & Mean & Median & & \\
\hline \multicolumn{7}{|l|}{ Firm Characteristics } \\
\hline Sales & 14178.78 & 6432.98 & 3879.72 & 1115.87 & $(6.86)$ & {$[<0.001]$} \\
\hline Market Value & 15973.21 & 6101.19 & 5727.86 & 1050.92 & $(2.88)$ & {$[<0.001]$} \\
\hline Total Assets & 23355.02 & 6476.18 & 4541.14 & 1173.07 & $(9.07)$ & {$[<0.001]$} \\
\hline $\mathrm{ROA}$ & 0.28 & 2.85 & 0.48 & 3.74 & $(-0.06)$ & {$[0.59]$} \\
\hline RET & 12.57 & 0.02 & 11.48 & 3.67 & $(0.09)$ & {$[0.42]$} \\
\hline Std Dev of ROA & 5.00 & 3.28 & 6.32 & 2.96 & $(-0.43)$ & {$[0.81]$} \\
\hline Std Dev of RET & 47.19 & 33.39 & 51.10 & 35.99 & $(-0.64)$ & {$[0.55]$} \\
\hline Investment Opp. & 4.78 & 2.78 & 2.98 & 2.45 & $(0.87)$ & {$[0.47]$} \\
\hline Altman-Z & 3.88 & 3.19 & 4.26 & 2.99 & $(-0.23)$ & {$[0.26]$} \\
\hline Institutional Holdings & 0.54 & 0.58 & 0.60 & 0.62 & $(-1.58)$ & {$[0.08]$} \\
\hline IsChair & 0.67 & 1.00 & 0.33 & 0.00 & $(4.25)$ & [0.001] \\
\hline Interlocked & 0.03 & 0.00 & 0.04 & 0.00 & $(-0.30)$ & [0.99] \\
\hline Top5Directors & 0.40 & 0.38 & 0.42 & 0.40 & $(-0.72)$ & {$[0.05]$} \\
\hline Top5Interlocked & 0.00 & 0.00 & 0.03 & 0.00 & $(-1.45)$ & {$[0.84]$} \\
\hline Top5Ownership & 0.02 & 0.00 & 0.03 & 0.01 & $(-0.86)$ & {$[0.12]$} \\
\hline \multicolumn{7}{|c|}{ Reservation Wage Variables } \\
\hline Outsider & 0.81 & 1.00 & 0.30 & 0.00 & $(6.65)$ & {$[<0.001]$} \\
\hline CEO of Prior Employer & 0.33 & 0.00 & 0.08 & 0.00 & $(5.52)$ & {$[0.02]$} \\
\hline Industry Knowledge & 0.28 & 0.00 & 0.12 & 0.00 & $(2.74)$ & {$[0.38]$} \\
\hline Market Wage & 4685.90 & 4162.18 & 4367.78 & 3624.02 & $(0.52)$ & {$[0.10]$} \\
\hline \multicolumn{7}{|l|}{ Compensation Variables } \\
\hline Total Compensation & 17711.53 & 11301.56 & 4086.57 & 2064.96 & $(11.00)$ & {$[<0.001]$} \\
\hline Salary & 799.37 & 667.65 & 522.76 & 478.78 & (5.96) & [0.002] \\
\hline Equity & 14341.32 & 7680.16 & 2816.13 & 953.20 & (10.08) & {$[<0.001]$} \\
\hline Portfolio Delta & 439.96 & 272.95 & 345.65 & 77.13 & $(0.12)$ & {$[0.001]$} \\
\hline
\end{tabular}

Sales, Market Value, and Total Assets are Compustat data \# 12, data \#199* data \#25, and data \#6 in millions. ROA is net income before extraordinary items (Compustat data \#18) scaled by Total Assets in percent. RET is the fiscal year return buy-and-hold return from CRSP in percent. Std Dev of ROA (Std Dev of RET) is the standard deviation of annual ROA (stock returns) in percent over the prior five fiscal years. Investment $O p p$ is the average fiscal year-end market-to-book ratio for the prior five years.

Altman- $Z$ is computed using Compustat data as follows: $1.2 *($ data \#179 / data \#6) $+1.4 *($ data \#36 / data $\# 6)+3.3 *($ data $\# 18+$ data \#16 + data \#15)/data \#6 + 0.6* (data \#199* data \#25)/ data \#181 +data \#12/ data \#6. Institutional Holdings is the fraction of shares held by institutions (13-F filers) as of fiscal year end. Is Chair is equal to 1 if the CEO is also chair of the Board, and 0 otherwise. Interlocked is equal to 1 if the CEO is interlocked with a member of his/her compensation committee, and 0 otherwise. Top5Directors is the fraction of the top five highest paid executives serving on the Board. Top5Interlocked is the fraction of the top five highest paid executives interlocked with a member the compensation committee. Top5Ownership is the fraction of share outstanding held by the top five highest paid executives, excluding options. Outsider equals 1 if the CEO's previous position was with a different firm, 0 otherwise. CEO of Prior Employer equals 1 if the CEO was also the CEO in his previous 
position, 0 otherwise. Industry Knowledge equals 1 if the CEO's previous position was with a different firm in the same Fama and French (1997) industry classification as the sample firm, and 0 otherwise. Market Wage is the mean compensation for CEOs joining a firm in the same year and Fama and French (1997) industry code in thousands. Total Compensation is the sum of salary (Salary), bonus, other annual, restricted stock granted (Restricted Stock), the risk-neutral value of options granted (Options), long term incentive payouts, and all other total, in thousands. Equity is the sum of Restricted Stock and Options. Portfolio Delta is the change in the risk-neutral dollar value of the CEO's equity portfolio for a $1 \%$ change in the firm's stock price (Core and Guay, 2000) in thousands. $t$-statistics (KolmogorovSmirnov $p$-values) are shown in parentheses (brackets) and test for a difference in means (distributions) between CEOs who used a talent agent and those that did not. The sample is composed of all new CEOs known to have used a talent agent and 1,761 other new CEOs (excluding co-CEOs) on Execucomp with non-missing start dates, compensation data, the requisite data on CRSP and Compustat to compute the above variables. 
Table 3. Propensity Score Matching

\section{Panel A. Propensity Score Estimation}

$\operatorname{Pr}($ Talent Agent $=1)=F(\boldsymbol{\alpha}$ Economic Determinants $+\boldsymbol{\beta}$ Governance Determinants $+\boldsymbol{\gamma}$ Reservation Wage Determinants $+\varepsilon$ )

\begin{tabular}{lcccccc}
\hline & \multicolumn{2}{c}{ Model 1 } & \multicolumn{2}{c}{ Model 2 } & \multicolumn{2}{c}{ Model 3 } \\
& coef & Z-stat & coef & Z-stat & coef & Z-stat \\
\hline Intercept & $-3.42^{* * *}$ & $(-6.32)$ & $-3.03^{* * *}$ & $(-5.48)$ & $-3.71^{* * *}$ & $(-5.76)$ \\
& & & & & & \\
Economic Determinants & & & & & & \\
\hline Log(Sales) & $0.18^{* * *}$ & $(2.77)$ & $0.19^{* * *}$ & $(2.86)$ & $0.19^{* * *}$ & $(2.58)$ \\
ROA & -0.01 & $(-1.13)$ & -0.01 & $(-0.79)$ & 0.00 & $(-0.56)$ \\
RET & 0.001 & $(0.59)$ & 0.001 & $(1.02)$ & $0.002^{* *}$ & $(1.98)$ \\
Std Dev of ROA & -0.01 & $(-0.75)$ & -0.01 & $(-0.62)$ & -0.01 & $(-0.59)$ \\
Std Dev of RET & 0.0003 & $(0.34)$ & 0.001 & $(0.81)$ & -0.0001 & $(-0.06)$ \\
Investment Opp. & 0.01 & $(1.54)$ & $0.01^{*}$ & $(1.64)$ & 0.01 & $(1.17)$ \\
Altman-Z & 0.00 & $(0.42)$ & 0.00 & $(0.78)$ & 0.00 & $(0.94)$
\end{tabular}

Governance Determinants

\begin{tabular}{|c|c|c|c|c|c|}
\hline Institutional Holdings & & $-1.00^{* * *}$ & $(-2.80)$ & $-1.08^{* * *}$ & $(-2.70)$ \\
\hline IsChair & & $0.54^{* * *}$ & $(3.35)$ & $0.44^{* *}$ & $(2.46)$ \\
\hline Interlocked & & 0.25 & $(0.46)$ & 0.23 & $(0.43)$ \\
\hline Top5Directors & & -0.42 & $(-1.07)$ & 0.07 & $(0.19)$ \\
\hline Top5Interlocked & & $-3.81^{* * *}$ & $(-3.18)$ & $-3.57^{* * *}$ & $(-3.21)$ \\
\hline Top5Ownership & & 0.40 & $(0.60)$ & 0.44 & $(0.68)$ \\
\hline Reservation Wage Deter & & & & & \\
\hline Outsider & & & & $0.88^{* * *}$ & (3.49) \\
\hline CEO of Prior Employer & & & & $0.39^{*}$ & (1.74) \\
\hline Industry Knowledge & & & & -0.11 & $(-0.57)$ \\
\hline Market Wage & & & & $0.00002^{*}$ & $(1.74)$ \\
\hline$\chi^{2} /$ Pseudo $\mathrm{R}^{2}$ & $12.62 / 5.85$ & 51.19 & & $104.82 /$ & 3.12 \\
\hline Akaike Info. Criterion & 348.183 & 336 & & 307.2 & \\
\hline $\mathrm{N}$ & 1,797 & & & 1,79 & \\
\hline
\end{tabular}


Panel B. Covariate Balance for Propensity Score Matched Sample

\begin{tabular}{lcccccc}
\hline & \multicolumn{2}{c}{ Treatment } & \multicolumn{2}{c}{ Control } & \multicolumn{2}{c}{ Diff in } \\
Ne36 & Means & KS \\
& Mean & Median & Mean & Median & $\begin{array}{c}\text { t-stat. } \\
\text { p-value }\end{array}$ \\
\hline Log(Sales) & 8.29 & 8.77 & 8.54 & 8.68 & $(-0.48)$ & {$[0.50]$} \\
ROA & 0.28 & 2.85 & 1.14 & 2.64 & $(-0.23)$ & {$[0.70]$} \\
RET & 12.57 & 0.02 & 36.47 & 2.60 & $(-0.87)$ & {$[0.50]$} \\
Std Dev of ROA & 5.00 & 3.28 & 3.67 & 2.47 & $(0.99)$ & {$[0.70]$} \\
Std Dev of RET & 47.19 & 33.39 & 57.25 & 37.82 & $(-0.85)$ & {$[0.70]$} \\
Investment Opp. & 4.78 & 2.78 & 8.34 & 2.16 & $(-0.95)$ & {$[0.50]$} \\
Altman-Z & 3.88 & 3.19 & 4.42 & 2.01 & $(-0.96)$ & {$[0.02]$} \\
Institutional Holdings & 0.54 & 0.58 & 0.48 & 0.46 & $(1.48)$ & {$[0.34]$} \\
IsChair & 0.67 & 1.00 & 0.83 & 1.00 & $(-2.29)$ & {$[0.70]$} \\
Interlocked & 0.03 & 0.00 & 0.06 & 0.00 & $(-0.55)$ & {$[0.99]$} \\
Top5Directors & 0.40 & 0.38 & 0.33 & 0.40 & $(1.55)$ & {$[0.70]$} \\
Top5Interlocked & 0.003 & 0.00 & 0.00 & 0.00 & $(2.91)$ & {$[0.50]$} \\
Top5Ownership & 0.02 & 0.00 & 0.02 & 0.00 & $(-0.14)$ & {$[0.07]$} \\
Outsider & 0.81 & 1.00 & 1.00 & 1.00 & $(-2.80)$ & {$[0.50]$} \\
CEO of Prior Employer & 0.33 & 0.00 & 0.72 & 1.00 & $(-3.17)$ & {$[0.01]$} \\
Industry Knowledge & 0.28 & 0.00 & 0.33 & 0.00 & $(-0.63)$ & {$[0.99]$} \\
Market Wage & 4685.90 & 4162.18 & 4583.97 & 3891.67 & $(0.13)$ & {$[0.50]$} \\
\hline
\end{tabular}

Panel A estimates the probability that a new CEO used a talent agent. Talent Agent is an indicator equal one if the CEO used a talent agent and zero otherwise, $F($.$) is the standard normal cumulative distribution$ function. All other variables are as previously defined. Huber-White robust $z$-statistics are shown in parentheses. $* * * / * * / *$ indicate statistical significance at the $1 \% / 5 \% / 10 \%$ level.

Panel B reports means and medians for the Propensity Score Matched Sample. The Propensity Score Sample is a one-to-one match sample between the treatment sample, those new CEOs who used a talent agent, and the control sample, those new CEOs who are most likely to use a talent agent, where the probability of using an agent is estimated according to Model 3 in Panel A. $t$-statistics based on standard errors clustered by firm and year are shown in parentheses and test for a difference in means between treatment and control samples. Kolmogorov-Smirnov (KS) $p$-values are shown in square brackets and test for a difference in distributions between treatment and control samples. 
Table 4. First Year Compensation Regressions

Panel A. Unmatched Sample

\begin{tabular}{|c|c|c|c|c|c|c|}
\hline & $\begin{array}{l}\text { Total Comp. } \\
\text { (1) }\end{array}$ & $\begin{array}{l}\text { Total Comp. } \\
\text { (2) }\end{array}$ & $\begin{array}{l}\text { Total Comp. } \\
\text { (3) }\end{array}$ & $\begin{array}{l}\text { Total Comp. } \\
\text { (4) }\end{array}$ & $\begin{array}{l}\text { Salary } \\
(5)\end{array}$ & $\begin{array}{l}\text { Equity } \\
\text { (6) }\end{array}$ \\
\hline Intercept & $\begin{array}{c}-10386.40^{* * *} \\
(-4.92)\end{array}$ & $\begin{array}{c}1366.87^{* * *} \\
(2.56)\end{array}$ & $\begin{array}{r}-524.69 \\
(-0.82)\end{array}$ & $\begin{array}{c}-12290.70^{* * *} \\
(-5.39)\end{array}$ & $\begin{array}{l}-436.70^{* * *} \\
(-11.66)\end{array}$ & $\begin{array}{c}-9652.48^{* * *} \\
(-4.35)\end{array}$ \\
\hline Talent Agent & $\begin{array}{c}11626.48^{* * *} \\
(5.53)\end{array}$ & $\begin{array}{c}13663.67^{* * *} \\
(7.57)\end{array}$ & $\begin{array}{c}12392.90^{* * *} \\
(6.82)\end{array}$ & $\begin{array}{c}10320.04^{* * *} \\
(5.01)\end{array}$ & $\begin{array}{c}141.58^{* *} \\
(2.35)\end{array}$ & $\begin{array}{c}8880.64^{* * *} \\
(4.25)\end{array}$ \\
\hline \multicolumn{7}{|l|}{ Economic Determinants } \\
\hline $\log ($ Sales $)$ & $\begin{array}{c}1752.24^{* * *} \\
(7.18)\end{array}$ & & & $\begin{array}{c}1563.06^{* * *} \\
(7.42)\end{array}$ & $\begin{array}{l}111.95^{* * *} \\
(21.74)\end{array}$ & $\begin{array}{c}1096.04^{* * *} \\
(5.66)\end{array}$ \\
\hline ROA & $\begin{array}{l}-16.93 \\
(-1.15)\end{array}$ & & & $\begin{array}{l}-6.79 \\
(-1.21)\end{array}$ & $\begin{array}{l}-0.74^{* *} \\
(-2.44)\end{array}$ & $\begin{array}{l}-1.62 \\
(-0.58)\end{array}$ \\
\hline RET & $\begin{array}{c}1.59 \\
(0.31)\end{array}$ & & & $\begin{array}{l}-0.99 \\
(-0.22)\end{array}$ & $\begin{array}{l}0.05 \\
(0.64)\end{array}$ & $\begin{array}{l}-1.90 \\
(-0.45)\end{array}$ \\
\hline Std Dev of ROA & $\begin{array}{l}79.55^{* * *} \\
(2.89)\end{array}$ & & & $\begin{array}{l}36.73^{*} \\
(1.68)\end{array}$ & $\begin{array}{l}1.27^{* * *} \\
(2.73)\end{array}$ & $\begin{array}{l}33.51 \\
(1.63)\end{array}$ \\
\hline Std Dev of RET & $\begin{array}{l}7.92 \\
(1.45)\end{array}$ & & & $\begin{array}{l}-0.98 \\
(-0.22)\end{array}$ & $\begin{array}{l}-0.10 \\
(-1.22)\end{array}$ & $\begin{array}{l}-0.20 \\
(-0.05)\end{array}$ \\
\hline Investment Opp. & $\begin{array}{l}29.44 \\
(1.11)\end{array}$ & & & $\begin{array}{l}18.71 \\
(1.04)\end{array}$ & $\begin{array}{c}0.62^{*} \\
(1.87)\end{array}$ & $\begin{array}{l}18.76 \\
(1.02)\end{array}$ \\
\hline Altman-Z & $\begin{array}{c}263.21^{* *} \\
(2.17)\end{array}$ & & & $\begin{array}{l}201.40^{* * * *} \\
(2.72)\end{array}$ & $\begin{array}{c}0.89 \\
(1.02)\end{array}$ & $\begin{array}{c}197.23^{* * *} \\
(2.72)\end{array}$ \\
\hline \multicolumn{7}{|l|}{ Governance Determinants } \\
\hline Institutional Holdings & & $\begin{array}{l}4449.86^{* * *} \\
(7.32)\end{array}$ & & $\begin{array}{l}79.50 \\
(0.17)\end{array}$ & $\begin{array}{c}128.33^{* * *} \\
(5.60)\end{array}$ & $\begin{array}{r}-539.10 \\
(-0.95)\end{array}$ \\
\hline IsChair & & $\begin{array}{c}732.50^{* *} \\
(2.25)\end{array}$ & & $\begin{array}{l}67.76 \\
(0.19)\end{array}$ & $\begin{array}{l}31.12^{* *} \\
(2.53)\end{array}$ & $\begin{array}{c}-49.46 \\
(-0.15)\end{array}$ \\
\hline Interlocked & & $\begin{array}{r}-2648.29 \\
(-3.41)\end{array}$ & & $\begin{array}{r}-1025.86 \\
(-1.45)\end{array}$ & $\begin{array}{l}-43.06^{* * *} \\
(-3.04)\end{array}$ & $\begin{array}{r}-815.78 \\
(-1.41)\end{array}$ \\
\hline Top5Directors & & $\begin{array}{r}-207.42 \\
(-0.14)\end{array}$ & & $\begin{array}{c}-700.63 \\
(-0.89)\end{array}$ & $\begin{array}{l}97.03^{* * *} \\
(2.78)\end{array}$ & $\begin{array}{r}-609.19 \\
(-0.83)\end{array}$ \\
\hline Top5Interlocked & & $\begin{array}{c}3366.01^{* *} \\
(1.96)\end{array}$ & & $\begin{array}{r}3055.48^{* *} \\
(2.17)\end{array}$ & $\begin{array}{l}-3.17 \\
(-0.09)\end{array}$ & $\begin{array}{c}2374.66^{* *} \\
(1.96)\end{array}$ \\
\hline Top5Ownership & & $\begin{array}{r}-2782.92^{*} \\
(-1.83)\end{array}$ & & $\begin{array}{r}-342.36 \\
(-0.27)\end{array}$ & $\begin{array}{l}37.17 \\
(0.61)\end{array}$ & $\begin{array}{r}-579.57 \\
(-0.48)\end{array}$ \\
\hline \multicolumn{7}{|c|}{ Reservation Wage Determinants } \\
\hline Outsider & & & $\begin{array}{c}1863.45^{* * *} \\
(3.92)\end{array}$ & $\begin{array}{c}2436.44^{* * *} \\
(4.96)\end{array}$ & $\begin{array}{l}-12.47 \\
(-0.82)\end{array}$ & $\begin{array}{c}2121.97^{* * *} \\
(5.33)\end{array}$ \\
\hline CEO of Prior Employer & & & $\begin{array}{c}20.61 \\
(0.04)\end{array}$ & $\begin{array}{c}-42.75 \\
(-0.11)\end{array}$ & $\begin{array}{l}18.97 \\
(0.86)\end{array}$ & $\begin{array}{l}88.78 \\
(0.21)\end{array}$ \\
\hline Industry Knowledge & & & $\begin{array}{r}-126.36 \\
(-0.15)\end{array}$ & $\begin{array}{r}-195.69 \\
(-0.30)\end{array}$ & $\begin{array}{l}-14.81 \\
(-0.73)\end{array}$ & $\begin{array}{l}18.71 \\
(0.03)\end{array}$ \\
\hline Market Wage & & & $\begin{array}{l}0.93^{* * *} \\
(6.36)\end{array}$ & $\begin{array}{l}0.87^{* * *} \\
(6.25)\end{array}$ & $\begin{array}{l}0.01^{* * *} \\
(3.50)\end{array}$ & $\begin{array}{l}0.83^{* * *} \\
(5.67)\end{array}$ \\
\hline Adjusted $\mathrm{R}^{2}$ & 20.17 & 8.64 & 27.44 & 38.02 & 50.53 & 34.55 \\
\hline $\mathrm{N}$ & 1797 & 1797 & 1797 & 1797 & 1797 & 1797 \\
\hline
\end{tabular}


Panel B. Propensity Score Matched Sample

\begin{tabular}{|c|c|c|c|c|c|c|}
\hline & \multicolumn{2}{|c|}{ Total Comp. } & \multicolumn{2}{|c|}{ Salary } & \multicolumn{2}{|c|}{ Equity } \\
\hline & Treatment & Control & Treatment & Control & Treatment & Control \\
\hline Mean & $17711.53^{* * *}$ & 8358.19 & 799.37 & 662.22 & $14341.32^{* * *}$ & 6428.78 \\
\hline Median & $11301.56^{* * *}$ & 3262.72 & 667.65 & 642.50 & $7680.16^{* * *}$ & 2135.46 \\
\hline$t$-statistic & \multicolumn{2}{|c|}{3.12} & \multicolumn{2}{|c|}{1.19} & \multicolumn{2}{|c|}{2.91} \\
\hline$z$-statistic & \multicolumn{2}{|c|}{3.08} & \multicolumn{2}{|c|}{0.79} & \multicolumn{2}{|c|}{2.90} \\
\hline KS p-value & \multicolumn{2}{|c|}{0.008} & \multicolumn{2}{|c|}{0.87} & \multicolumn{2}{|c|}{0.008} \\
\hline
\end{tabular}

Panel A presents regression results from estimating first year pay as a function of economic, governance, and reservation wage determinants. In each regression we exclude those observations with a Cook-D greater than 1. Talent Agent is a variable equal 1 if the CEO used a talent agent, and 0 otherwise. All other variables are as previously defined. $t$-statistics based on standard errors clustered by firm and year are shown in parentheses. $* * * / * * / *$ indicate statistical significance at the $1 \% / 5 \% / 10 \%$ level.

Panel B tests for differences in means, medians, and distribution of executive compensation between treatment and control firms for the Propensity Score Matched Sample. $t$-statistics based on standard errors clustered by firm and year are shown in parentheses and test for a difference in means between treatment and control samples. Wilcoxon $z$-statistics are shown in angle brackets and test for difference in ranks between the samples, and Kolmogorov-Smirnov (KS) $p$-values are shown in square brackets and test for a difference in distributions between treatment and control samples. $* * * / * * * *$ indicate a statistically significant difference at the $1 \% / 5 \% / 10 \%$ level. 
Table 5. Compensation Regressions For Years Subsequent to Appointment

\section{Panel A. Unmatched Sample}

\begin{tabular}{|c|c|c|c|c|c|c|}
\hline & $\begin{array}{l}\text { Total Comp. } \\
\text { (1) }\end{array}$ & $\begin{array}{c}\text { Total Comp. } \\
\text { (2) }\end{array}$ & $\begin{array}{l}\text { Total Comp. } \\
\text { (3) }\end{array}$ & $\begin{array}{l}\text { Total Comp. } \\
\text { (4) }\end{array}$ & $\begin{array}{l}\text { Salary } \\
(5)\end{array}$ & $\begin{array}{l}\text { Equity } \\
\text { (6) }\end{array}$ \\
\hline Intercept & $\begin{array}{c}-13590.80^{* * *} \\
(-9.83)\end{array}$ & $\begin{array}{c}913.49 \\
(1.58)\end{array}$ & $\begin{array}{c}3188.66^{* * *} \\
(7.58)\end{array}$ & $\begin{array}{c}-14216.80^{* * *} \\
(-10.38)\end{array}$ & $\begin{array}{c}-647.04^{* * *} \\
(-9.49)\end{array}$ & $\begin{array}{c}-9953.37^{* * *} \\
(-8.47)\end{array}$ \\
\hline Talent Agent & $\begin{array}{c}3853.75^{* * *} \\
(2.70)\end{array}$ & $\begin{array}{c}6764.94^{* * *} \\
(3.79)\end{array}$ & $\begin{array}{c}6276.66^{* * *} \\
(3.64)\end{array}$ & $\begin{array}{c}2745.79^{* *} \\
(2.08)\end{array}$ & $\begin{array}{c}180.87^{* *} \\
(2.03)\end{array}$ & $\begin{array}{r}1759.60^{*} \\
(1.73)\end{array}$ \\
\hline \multicolumn{7}{|l|}{ Economic Determinants } \\
\hline Log(Sales) & $\begin{array}{c}2201.51^{* * *} \\
(11.46)\end{array}$ & & & $\begin{array}{c}2136.48^{* * *} \\
(10.66)\end{array}$ & $\begin{array}{l}154.19^{* * *} \\
(15.04)\end{array}$ & $\begin{array}{c}1416.72^{* * *} \\
(8.20)\end{array}$ \\
\hline ROA & $\begin{array}{c}-12.91 \\
(-1.03)\end{array}$ & & & $\begin{array}{c}-15.12 \\
(-1.31)\end{array}$ & $\begin{array}{l}-0.97 \\
(-1.41)\end{array}$ & $\begin{array}{c}-13.21 \\
(-1.45)\end{array}$ \\
\hline RET & $\begin{array}{c}6.30 \\
(1.61)\end{array}$ & & & $\begin{array}{c}5.93 \\
(1.58)\end{array}$ & $\begin{array}{l}-0.02 \\
(-0.28)\end{array}$ & $\begin{array}{c}4.18 \\
(1.21)\end{array}$ \\
\hline Std Dev of ROA & $\begin{array}{l}55.96^{* * *} \\
(3.32)\end{array}$ & & & $\begin{array}{l}46.84^{* * *} \\
(3.09)\end{array}$ & $\begin{array}{l}1.78^{* * *} \\
(2.69)\end{array}$ & $\begin{array}{l}35.00^{* * *} \\
(2.86)\end{array}$ \\
\hline Std Dev of RET & $\begin{array}{l}12.42^{* * *} \\
(2.86)\end{array}$ & & & $\begin{array}{l}8.47^{* *} \\
(2.18)\end{array}$ & $\begin{array}{c}0.07 \\
(0.50)\end{array}$ & $\begin{array}{l}9.07^{* * *} \\
(2.69)\end{array}$ \\
\hline Investment Opp. & $\begin{array}{l}2.41 \\
(0.70)\end{array}$ & & & $\begin{array}{c}2.19 \\
(0.69)\end{array}$ & $\begin{array}{c}0.13 \\
(1.00)\end{array}$ & $\begin{array}{l}1.12 \\
(0.52)\end{array}$ \\
\hline Altman-Z & $\begin{array}{c}198.18^{* * *} \\
(5.91)\end{array}$ & & & $\begin{array}{c}201.31 \\
(6.17)\end{array}$ & $\begin{array}{r}2.39^{*} \\
(1.88)\end{array}$ & $\begin{array}{c}187.47^{* * *} \\
(6.10)\end{array}$ \\
\hline \multicolumn{7}{|l|}{ Governance Determinants } \\
\hline Institutional Holdings & & $\begin{array}{c}3244.50^{* * *} \\
(4.51)\end{array}$ & & $\begin{array}{r}453.48 \\
(0.77)\end{array}$ & $\begin{array}{c}149.16^{* * *} \\
(4.61)\end{array}$ & $\begin{array}{r}100.44 \\
(0.19)\end{array}$ \\
\hline IsChair & & $\begin{array}{c}1865.40^{* * * *} \\
(5.62)\end{array}$ & & $\begin{array}{c}487.30^{* *} \\
(1.82)\end{array}$ & $\begin{array}{l}70.49^{* * *} \\
(6.20)\end{array}$ & $\begin{array}{c}171.15 \\
(0.81)\end{array}$ \\
\hline Interlocked & & $\begin{array}{r}-1044.20 \\
(-1.58)\end{array}$ & & $\begin{array}{r}-786.88 \\
(-1.49)\end{array}$ & $\begin{array}{l}-40.31^{*} \\
(-1.94)\end{array}$ & $\begin{array}{c}-1089.54^{* *} \\
(-2.08)\end{array}$ \\
\hline Top5Directors & & $\begin{array}{r}1080.48 \\
(1.11)\end{array}$ & & $\begin{array}{r}-1123.55 \\
(-1.38)\end{array}$ & $\begin{array}{l}17.46 \\
(0.36)\end{array}$ & $\begin{array}{r}-920.33 \\
(-1.18)\end{array}$ \\
\hline Top5Interlocked & & $\begin{array}{r}1842.98 \\
(0.67)\end{array}$ & & $\begin{array}{r}3692.41 \\
\quad(1.58)\end{array}$ & $\begin{array}{c}-179.91^{* *} \\
(-2.53)\end{array}$ & $\begin{array}{r}3575.85 \\
(1.50)\end{array}$ \\
\hline Top5Ownership & & $\begin{array}{c}-6161.44^{* * *} \\
(-3.40)\end{array}$ & & $\begin{array}{r}-1489.73 \\
(-0.95)\end{array}$ & $\begin{array}{l}-61.09 \\
(-0.79)\end{array}$ & $\begin{array}{r}-1100.32 \\
(-0.84)\end{array}$ \\
\hline \multicolumn{7}{|c|}{ Reservation Wage Determinants } \\
\hline Outsider & & & $\begin{array}{c}125.94 \\
(0.35)\end{array}$ & $\begin{array}{l}814.45^{* * *} \\
(2.58)\end{array}$ & $\begin{array}{l}49.62^{* * *} \\
(2.98)\end{array}$ & $\begin{array}{c}684.11^{* * *} \\
(3.02)\end{array}$ \\
\hline $\begin{array}{l}\text { CEO of Prior } \\
\text { Employer }\end{array}$ & & & $\begin{array}{c}1553.71^{* *} \\
(1.65)\end{array}$ & $\begin{array}{c}1579.58^{* *} \\
(2.16)\end{array}$ & $\begin{array}{l}-3.27 \\
(-0.09)\end{array}$ & $\begin{array}{c}1011.37^{* * *} \\
(1.97)\end{array}$ \\
\hline Industry Knowledge & & & $\begin{array}{r}-420.61 \\
(-0.74)\end{array}$ & $\begin{array}{r}-699.56 \\
(-1.41)\end{array}$ & $\begin{array}{l}-21.79 \\
(-0.91)\end{array}$ & $\begin{array}{r}-509.50 \\
(-1.29)\end{array}$ \\
\hline Market Wage & & & $\begin{array}{l}0.25^{* * *} \\
(3.31)\end{array}$ & $\begin{array}{c}0.20^{* * *} \\
(3.62)\end{array}$ & $\begin{array}{c}0.01^{*} \\
(1.92)\end{array}$ & $\begin{array}{c}0.14^{* * *} \\
(3.82)\end{array}$ \\
\hline Adjusted $\mathrm{R}^{2}$ & 20.56 & 5.18 & 4.29 & 22.66 & 50.53 & 13.78 \\
\hline $\mathrm{N}$ & 5333 & 5333 & 5333 & 5333 & 5333 & 5333 \\
\hline
\end{tabular}


Panel B. Propensity Score Matched Sample

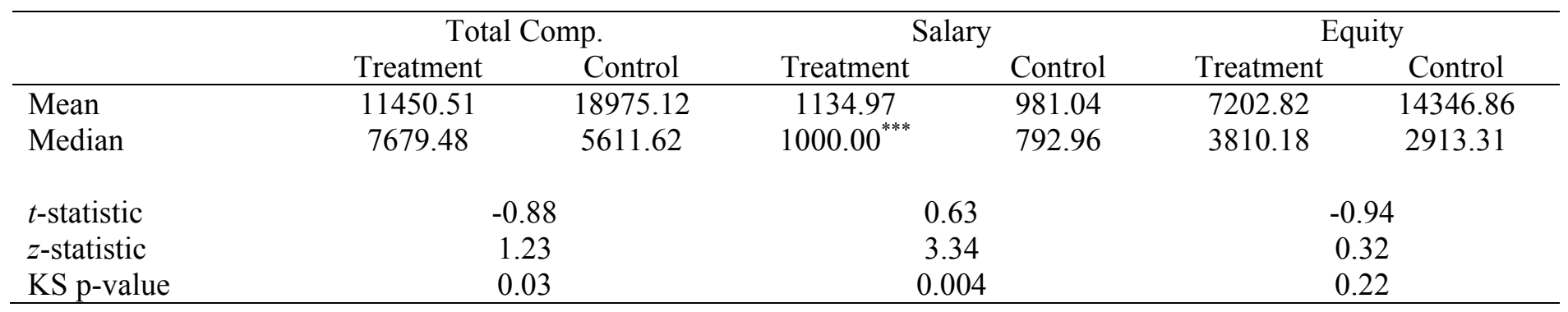

Panel A presents regression results from estimating pay (for all subsequent years subsequent to CEO appointment) as a function of economic, governance, and reservation wage determinants. In each regression we exclude those observations with a Cook-D greater than 1. Talent Agent is a variable equal 1 if the CEO used a talent agent, and 0 otherwise. All other variables are as previously defined. $t$-statistics based on standard errors clustered by firm and year are shown in parentheses. $* * * / * * *$ indicate statistical significance at the $1 \% / 5 \% / 10 \%$ level.

Panel B tests for differences in means, medians, and distribution of executive compensation between treatment and control firms for the Propensity Score Matched Sample. $t$-statistics based on standard errors clustered by firm and year are shown in parentheses and test for a difference in means between treatment and control samples. Wilcoxon $z$-statistics are shown in angle brackets and test for difference in ranks between the samples, and Kolmogorov-Smirnov (KS) $p$-values are shown in square brackets and test for a difference in distributions between treatment and control samples. $* * * / * * / *$ indicate a statistically significant difference at the $1 \% / 5 \% / 10 \%$ level. 
Table 6. Equity Incentives

\section{Panel A. Unmatched Sample}

Dependent Variable: Portfolio Delta

\begin{tabular}{|c|c|c|c|c|}
\hline & \multicolumn{2}{|c|}{ First Year } & \multicolumn{2}{|c|}{ Subsequent Years } \\
\hline & Coef. & t-stat & Coef. & t-stat \\
\hline Intercept & $-2.03^{* * *}$ & $(-16.67)$ & $-2.64^{* * *}$ & $(-12.95)$ \\
\hline Talent Agent & $0.72^{* * *}$ & (4.77) & $0.72^{* * *}$ & $(4.99)$ \\
\hline Log(Sales) & $0.33^{* * *}$ & $(17.82)$ & $0.44^{* * *}$ & $(19.63)$ \\
\hline Std Dev of ROA & $0.01^{* * *}$ & $(5.06)$ & $0.01^{* * *}$ & $(2.95)$ \\
\hline Std Dev of RET & 0.001 & $(0.96)$ & $0.003^{* *}$ & $(2.28)$ \\
\hline Investment Opp. & 0.01 & $(1.50)$ & 0.00 & $(0.95)$ \\
\hline Altman-Z & $0.02^{* * *}$ & $(2.85)$ & $0.04^{* *}$ & $(2.22)$ \\
\hline Institutional Holdings & $1.05^{* * *}$ & $(8.24)$ & $1.53^{* * *}$ & $(10.10)$ \\
\hline IsChair & $0.13^{*}$ & $(1.75)$ & $0.22^{* * *}$ & $(3.69)$ \\
\hline Interlocked & 0.13 & (1.01) & 0.08 & $(0.72)$ \\
\hline Top5Directors & $0.48^{* * *}$ & $(4.30)$ & 0.11 & $(0.61)$ \\
\hline Top5Interlocked & 0.19 & $(0.50)$ & 0.30 & $(0.58)$ \\
\hline Adjusted $\mathrm{R}^{2}$ & \multicolumn{2}{|c|}{24.92} & \multicolumn{2}{|c|}{35.86} \\
\hline $\mathrm{N}$ & \multicolumn{2}{|c|}{1797} & \multicolumn{2}{|c|}{5333} \\
\hline
\end{tabular}

Panel B. Propensity Score Matched Sample

\begin{tabular}{lcccc}
\hline & \multicolumn{2}{c}{ Incentives, First-Year } & \multicolumn{2}{c}{ Incentives, } \\
& Treatment & Control & Treatment & Control \\
\hline Mean & $2.53^{*}$ & 2.00 & $3.48^{*}$ & 2.88 \\
Median & 3.00 & 2.00 & $4.00^{* * *}$ & 3.00 \\
& & & & \\
$t$-statistic & & & \multicolumn{2}{c}{1.75} \\
$z$-statistic & 1.64 & \multicolumn{2}{c}{3.06} \\
KS p-value & 1.58 & \multicolumn{2}{c}{0.006} \\
\hline
\end{tabular}

Panel A presents regression results from estimating equity incentives of first year CEOs and non-first year CEOs as a function of economic and governance determinants. Talent Agent is a variable equal 1 if the CEO used a talent, and 0 otherwise. Our measure of equity incentives is the quintile rank of the change in the risk-neutral value of the CEO's equity portfolio for a $1 \%$ change in the price of the underlying stock, Portfolio Delta. We use the quintile rank of Portfolio Delta in our analysis to reduce measurement associated with computing the equity portfolio delta (Core and Guay, 2002). $t$-statistics based on standard errors clustered by firm and year are shown in parentheses. $* * * / * * / *$ indicate statistical significance at the $1 \% / 5 \% / 10 \%$ level.

Panel B tests for differences in means, medians, and distribution of equity incentives between treatment and control firms for the Propensity Score Matched Sample. $t$-statistics based on standard errors clustered by firm and year are shown in parentheses and test for a difference in means between treatment and control samples. Wilcoxon $z$-statistics are shown in angle brackets and test for difference in ranks between the samples, and Kolmogorov-Smirnov (KS) $p$-values are shown in square brackets and test for a difference in distributions between treatment and control samples. $* * * / * * / *$ indicate a statistically significant difference at the $1 \% / 5 \% / 10 \%$ level. 
Table 7. Future Operating Performance Regressions

Panel A. Unmatched Sample

$R O A_{t+T}=\alpha_{0}+\alpha_{1}$ Talent Agent $+\alpha_{2} \log ($ Sales $)+\alpha_{3}$ InvestmentOpp $+\alpha_{4} R O A+\alpha_{5}$ Std Dev of ROA $+\varepsilon$

\begin{tabular}{lccrrrr}
\hline Dependent Var.: & \multicolumn{2}{c}{$R$} & \multicolumn{2}{c}{$R O A_{t+1}$} & \multicolumn{2}{c}{$R O A_{t+3}$} \\
\hline Coef. & t-stat & Coef. & t-stat & Coef. & t-stat \\
\hline Talent Agent & $1.79^{* *}$ & $(2.35)$ & $1.55^{* *}$ & $(2.02)$ & -0.40 & $(-0.24)$ \\
Log(Sales) & 0.19 & $(1.11)$ & $0.63^{* * *}$ & $(4.16)$ & $0.73^{* * *}$ & $(4.00)$ \\
Std Dev of ROA & $-0.06^{* *}$ & $(-2.46)$ & $-0.06^{* *}$ & $(-2.51)$ & -0.05 & $(-1.60)$ \\
Investment Opp. & $-0.00^{* * *}$ & $(-0.09)$ & 0.01 & $(1.05)$ & 0.02 & $(1.29)$ \\
ROA & $0.45^{*}$ & $(11.25)$ & $0.34^{* * *}$ & $(6.80)$ & $0.36^{* * *}$ & $(6.53)$ \\
Adjusted R & & \multicolumn{2}{c}{32.00} & & \multicolumn{2}{c}{30.37} \\
N & \multicolumn{2}{c}{38.07} & \multicolumn{2}{c}{1666} & \multicolumn{2}{c}{1666} \\
\hline
\end{tabular}

Panel B. Propensity Score Matched Sample

\begin{tabular}{lcccccc}
\hline & \multicolumn{2}{c}{$R^{2} A_{t+1}$} & \multicolumn{2}{c}{$R O A_{t+3}$} & \multicolumn{2}{c}{$R O A_{t+5}$} \\
& Treatment & Control & Treatment & Control & Treatment & Control \\
\hline Mean & $4.48^{*}$ & -1.51 & $4.64^{* *}$ & -1.11 & 4.01 & 1.48 \\
Median & $5.61^{* *}$ & 1.92 & $4.78^{* *}$ & 1.68 & $4.78^{*}$ & 2.34 \\
& & & & & & \\
$t$-statistic & 1.91 & & 2.07 & 0.65 \\
$z$-statistic & 2.51 & 2.49 & 2.00 \\
KS p-value & 0.03 & 0.05 & 0.05
\end{tabular}

Panel A presents regressions of future operating performance on an indicator variable for whether the CEO used a talent agent (Talent Agent). $R O A_{t+T}$ is the average $R O A$ in percent over the future $T$ years. All other variables are as previously defined. $t$-statistics based on standard errors clustered by firm and year are shown in parentheses. $* * * / * * / *$ indicate statistical significance at the $1 \% / 5 \% / 10 \%$ level.

Panel B tests for differences in means, medians, and distribution of future operating performance between treatment and control firms for the Propensity Score Matched Sample. $t$-statistics based on standard errors clustered by firm and year are shown in parentheses and test for a difference in means between treatment and control samples. Wilcoxon $z$-statistics are shown in angle brackets and test for difference in ranks between the samples, and Kolmogorov-Smirnov (KS) $p$-values are shown in square brackets and test for a difference in distributions between treatment and control samples. $* * * / * * / *$ indicate a statistically significant difference at the $1 \% / 5 \% / 10 \%$ level. 
Table 8. Abnormal Stock Return Regressions

$\left(r_{i}-r_{f}\right)=\alpha_{1}+\alpha_{2}$ Talent Agent $+\beta_{1} M K T R F+\beta_{2} S M B+\beta_{3} H M L+\beta_{4} M O M+$

$\beta_{5}$ Talent Agent $* M K T R F+\beta_{6}$ Talent Agent $* S M B+\beta_{7}$ Talent Agent $* H M L+\beta_{8}$ Talent Agent $* M O M+v$

Panel A. Unmatched Sample

\begin{tabular}{|c|c|c|c|c|c|c|c|c|}
\hline \multirow{2}{*}{$\begin{array}{l}\text { Event Window: } \\
\text { Variable }\end{array}$} & \multicolumn{2}{|c|}{$t=-24 \ldots-13$} & \multicolumn{2}{|c|}{$t=-12 \ldots-1$} & \multicolumn{2}{|c|}{$t=0 \ldots 12$} & \multicolumn{2}{|c|}{$t=13 \ldots 24$} \\
\hline & Coef. & t-stat & Coef. & t-stat & Coef. & t-stat & Coef. & t-stat \\
\hline Intercept & 0.19 & $(1.45)$ & $-0.60^{* * *}$ & $(-3.78)$ & $0.32^{* *}$ & $(2.39)$ & 0.05 & $(0.32)$ \\
\hline Talent Agent & $-1.49^{* * *}$ & $(-2.89)$ & 0.71 & $(0.98)$ & $1.78^{* *}$ & $(2.53)$ & 0.30 & $(0.50)$ \\
\hline MKTRF & $1.09^{* * *}$ & $(31.82)$ & $1.15^{* * *}$ & $(27.99)$ & $1.13^{* * *}$ & $(27.47)$ & $1.08^{* * *}$ & $(30.03)$ \\
\hline SMB & $0.58^{* * *}$ & $(11.02)$ & $0.56^{* * *}$ & $(10.83)$ & $0.61^{* * *}$ & $(13.36)$ & $0.57^{* * *}$ & $(14.15)$ \\
\hline HML & $0.31^{* * *}$ & $(5.42)$ & $0.47^{* * *}$ & $(8.83)$ & $0.51^{* * *}$ & $(8.29)$ & $0.51^{* * *}$ & $(9.77)$ \\
\hline MOM & $-0.23^{* * *}$ & $(-7.51)$ & $-0.23^{* * *}$ & $(-4.90)$ & $-0.33^{* * *}$ & $(-8.60)$ & $-0.23^{* * *}$ & $(-6.77)$ \\
\hline Talent Agent*MKTRF & 0.02 & $(0.15)$ & -0.04 & $(-0.24)$ & -0.29 & $(-1.53)$ & -0.18 & $(-1.12)$ \\
\hline Talent Agent*SMB & $-0.29^{* *}$ & $(-2.32)$ & $-0.56^{* * *}$ & $(-3.18)$ & $-0.68^{* * *}$ & $(-3.36)$ & $-0.34^{* *}$ & $(-1.96)$ \\
\hline Talent Agent*HML & -0.44 & $(-0.23)$ & -0.40 & $(-0.18)$ & $-0.49^{* *}$ & $(-2.45)$ & -0.42 & $(-0.17)$ \\
\hline Talent Agent*MOM & -0.12 & $(-0.88)$ & 0.04 & $(0.32)$ & -0.36 & $(-2.63)$ & $0.27^{* *}$ & $(2.14)$ \\
\hline Adjusted $\mathrm{R}^{2}$ & \multirow{2}{*}{\multicolumn{2}{|c|}{$\begin{array}{r}13.43 \\
21318\end{array}$}} & \multirow{2}{*}{\multicolumn{2}{|c|}{$\begin{array}{l}12.83 \\
21509\end{array}$}} & \multirow{2}{*}{\multicolumn{2}{|c|}{$\begin{array}{r}12.82 \\
23328\end{array}$}} & \multirow{2}{*}{\multicolumn{2}{|c|}{$\begin{array}{r}12.06 \\
20503\end{array}$}} \\
\hline $\mathrm{N}$ & & & & & & & & \\
\hline
\end{tabular}


Panel B. Propensity Score Matched Sample

\begin{tabular}{|c|c|c|c|c|c|c|c|c|}
\hline Event Window: & \multicolumn{2}{|c|}{$t=-24 \ldots-13$} & \multicolumn{2}{|c|}{$t=-12 \ldots-1$} & \multicolumn{2}{|c|}{$t=0 \ldots 12$} & \multicolumn{2}{|c|}{$t=13 \ldots 24$} \\
\hline Variable & Coef. & t-stat & Coef. & t-stat & Coef. & t-stat & Coef. & t-stat \\
\hline Intercept & -0.16 & $(-0.32)$ & -0.86 & $(-1.29)$ & -0.10 & $(-0.11)$ & 1.31 & $(1.56)$ \\
\hline Talent Agent & -1.14 & $(-1.56)$ & 0.96 & $(0.99)$ & $2.21^{* *}$ & $(2.17)$ & -0.97 & $(-1.01)$ \\
\hline MKTRF & $1.33^{* * *}$ & $(9.69)$ & $1.27^{* * *}$ & $(8.24)$ & $1.13^{* * *}$ & (4.61) & $0.65^{* * *}$ & $(2.86)$ \\
\hline SMB & -0.03 & $(-0.17)$ & 0.23 & (1.01) & $0.45^{*}$ & (1.82) & $0.64^{* * *}$ & $(2.71)$ \\
\hline HML & $0.35^{* *}$ & $(2.00)$ & $0.43^{*}$ & $(1.72)$ & 0.43 & (1.34) & $0.48^{*}$ & $(1.78)$ \\
\hline MOM & $-0.27^{* *}$ & $(-2.20)$ & -0.03 & $(-0.26)$ & -0.31 & $(-1.23)$ & $-0.56^{* * *}$ & $(-2.73)$ \\
\hline Talent Agent*MKTRF & -0.23 & $(-1.21)$ & -0.16 & $(-0.76)$ & -0.29 & $(-0.89)$ & 0.24 & $(0.91)$ \\
\hline Talent Agent*SMB & 0.32 & $(1.42)$ & -0.22 & $(-0.81)$ & -0.52 & $(-1.52)$ & -0.41 & $(-1.49)$ \\
\hline Talent Agent*HML & -0.85 & $(-0.33)$ & 0.46 & $(0.01)$ & -0.41 & $(-1.09)$ & -0.19 & $(-0.05)$ \\
\hline Talent Agent*MOM & -0.09 & $(-0.49)$ & -0.16 & $(-0.95)$ & $-0.38^{* *}$ & $(-2.15)$ & $0.60^{* * *}$ & $(2.69)$ \\
\hline Adjusted $\mathrm{R}^{2}$ & & 18.54 & & 41 & & 32 & & .59 \\
\hline $\mathrm{N}$ & & 840 & & & & & & \\
\hline
\end{tabular}

Panels A and B present results from estimating average monthly abnormal returns (alpha). Regressions are estimated over four non-overlapping windows spanning the twenty four months prior to and the twenty four months subsequent to the month the CEO was hired $(t=0)$. $r_{i}$ is the monthly firm return, $r_{f}$ is the monthly risk-free interest rate, $M K T R F, S M B, H M L$, and $M O M$ are the monthly Fama and French (1993) and Carhart (1997) factors, and Talent Agent is a variable equal 1 if the CEO used a talent agent, and 0 otherwise. $t$-statistics are shown in parentheses and are based on standard errors clustered by date. Average abnormal returns are the intercept (alpha) from the respective regression, and the difference in average abnormal returns between firms that hired a CEO who used an agent and those that hired CEOs who did not use an agent is the coefficient on Talent Agent. $* * * / * * / *$ indicate statistical significance at the $1 \% / 5 \% / 10 \%$ level. 
Table 9. CEO Appointment Date Abnormal Returns

Panel A. Unmatched Sample.

\begin{tabular}{|c|c|c|c|c|c|c|}
\hline $\begin{array}{l}\text { Measure: } \\
\text { Interval: }\end{array}$ & $\begin{array}{l}\text { Mkt. Adjusted } \\
\text { BHAR }(-5,+5)\end{array}$ & $\begin{array}{l}\text { Mkt. Adjusted } \\
\text { BHAR }(-5,0)\end{array}$ & $\begin{array}{c}\text { Mkt. Adjusted } \\
\text { BHAR }(1,+5)\end{array}$ & $\begin{array}{l}\text { Size Adjusted } \\
\text { BHAR }(-5,+5)\end{array}$ & $\begin{array}{c}\text { Size Adjusted } \\
\text { BHAR }(-5,0)\end{array}$ & $\begin{array}{l}\text { Size Adjusted } \\
\text { BHAR }(1,+5)\end{array}$ \\
\hline Intercept & $\begin{array}{l}0.47 \\
(1.55)\end{array}$ & $\begin{array}{l}0.17 \\
(0.85)\end{array}$ & $\begin{array}{l}0.34 \\
(1.53)\end{array}$ & $\begin{array}{c}0.34 \\
(1.16)\end{array}$ & $\begin{array}{c}0.04 \\
(0.21)\end{array}$ & $\begin{array}{l}0.34 \\
(1.56)\end{array}$ \\
\hline Talent Agent & $\begin{array}{l}5.58^{* * *} \\
(2.67)\end{array}$ & $\begin{array}{l}3.80^{* * *} \\
(3.15)\end{array}$ & $\begin{array}{l}1.56 \\
(1.07)\end{array}$ & $\begin{array}{l}5.60^{* * *} \\
(2.65)\end{array}$ & $\begin{array}{l}3.87^{* * *} \\
(3.23)\end{array}$ & $\begin{array}{l}1.52 \\
(1.03)\end{array}$ \\
\hline $\mathrm{N}$ & 1794 & 1794 & 1794 & 1794 & 1794 & 1794 \\
\hline
\end{tabular}

Panel B. Propensity Score Matched Sample

\begin{tabular}{|c|c|c|c|c|c|c|}
\hline $\begin{array}{l}\text { Measure: } \\
\text { Interval: }\end{array}$ & $\begin{array}{l}\text { Mkt. Adjusted } \\
\text { BHAR }(-5,+5)\end{array}$ & $\begin{array}{l}\text { Mkt. Adjusted } \\
\text { BHAR }(-5,0)\end{array}$ & $\begin{array}{l}\text { Mkt. Adjusted } \\
\text { BHAR }(1,+5)\end{array}$ & $\begin{array}{l}\text { Size Adjusted } \\
\text { BHAR }(-5,+5)\end{array}$ & $\begin{array}{c}\text { Size Adjusted } \\
\text { BHAR }(-5,0)\end{array}$ & $\begin{array}{l}\text { Size Adjusted } \\
\operatorname{BHAR}(1,+5)\end{array}$ \\
\hline Intercept & $\begin{array}{l}0.60 \\
(0.24)\end{array}$ & $\begin{array}{l}2.92^{*} \\
(1.67)\end{array}$ & $\begin{array}{l}-2.32^{*} \\
(-1.70)\end{array}$ & $\begin{array}{c}0.62 \\
(0.25)\end{array}$ & $\begin{array}{c}2.95^{*} \\
(1.67)\end{array}$ & $\begin{array}{l}-2.32^{*} \\
(-1.70)\end{array}$ \\
\hline Talent Agent & $\begin{array}{l}5.45^{*} \\
(1.66)\end{array}$ & $\begin{array}{l}1.05 \\
(0.50)\end{array}$ & $\begin{array}{l}4.22^{* *} \\
(2.08)\end{array}$ & $\begin{array}{l}5.32 \\
(1.62)\end{array}$ & $\begin{array}{l}0.96 \\
(0.46)\end{array}$ & $\begin{array}{l}4.17^{* *} \\
(2.05)\end{array}$ \\
\hline $\mathrm{N}$ & 36 & 36 & 36 & 36 & 36 & 36 \\
\hline
\end{tabular}

Panels A and B present results from regressions of buy-and hold abnormal returns $(B H A R)$ on an indicator variable for whether the CEO used a talent agent (Talent Agent). Market (size) adjusted BHAR are calculated as the compounded return of the firm over the daily event interval specified, minus that of the CRSP value-weighted index (firm $i$ 's size decile). Event day 0 is defined as the date Execucomp records as the day the executive became CEO (appointment date). If no trading occurs on the appointment date we define event day 0 as the next trading day. $t$-statistics based on standard errors clustered by firm and year are shown in parentheses. $* * * / * * / *$ indicate statistical significance at the $1 \% / 5 \% / 10 \%$ level. 